\title{
Sediment Quantity and Quality in Three Impoundments in Massachusetts
}

By MARC J. ZIMMERMAN and ROBERT F. BREAULT

Water-Resources Investigations Report 03-4013

In cooperation with the MASSACHUSETTS DEPARTMENT OF ENVIRONMENTAL PROTECTION, MASSACHUSETTS DEPARTMENT OF FISHERIES, WILDLIFE, AND ENVIRONMENTAL LAW ENFORCEMENT RIVER RESTORE PROGRAM, MASSACHUSETTS EXECUTIVE OFFICE OF ENVIRONMENTAL AFFAIRS' WATERSHED INITIATIVE, and the MASSACHUSETTS DEPARTMENT OF ENVIRONMENTAL MANAGEMENT

Northborough, Massachusetts

2003 


\title{
U.S. DEPARTMENT OF THE INTERIOR
}

\author{
GALE A. NORTON, Secretary
}

\section{U.S. GEOLOGICAL SURVEY}

Charles G. Groat, Director

This project was financed partially with Federal funds from the U.S. Environmental Protection Agency (USEPA) to the Massachusetts Department of Environmental Protection (the Department) under Section 104(b)3 of the Clean Water Act. The contents do not necessarily reflect the views and policies of the USEPA or of the Department, nor does the mention of trade names or commercial products constitute endorsement or recommendation for use by the U.S. Government.

This project also received funding from the Massachusetts Department of Fisheries, Wildlife, and Environmental Law Enforcement's River Restore Program, the Executive Office of Environmental Affairs' Massachusetts Watershed Initiative, and the Massachusetts Department of Environmental Management.

For additional information write to:

Chief, Massachusetts-Rhode Island District

U.S. Geological Survey

10 Bearfoot Road

Northborough, Massachusetts 01532

or visit our Web site at

http://ma.water.usgs.gov
Copies of this report can be purchased from:

U.S. Geological Survey

Branch of Information Services

Box 25286

Denver, C0 80225-0286 


\section{CONTENTS}

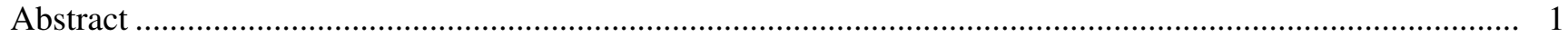

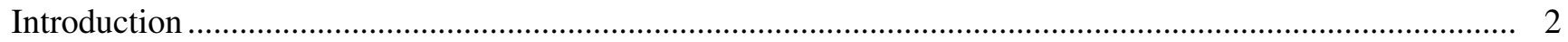

Previous Studies and Historical Information ............................................................................ 2

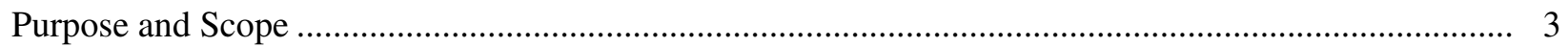

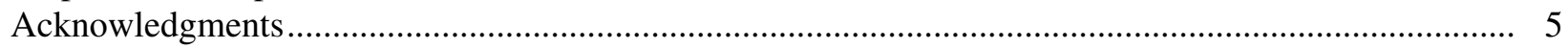

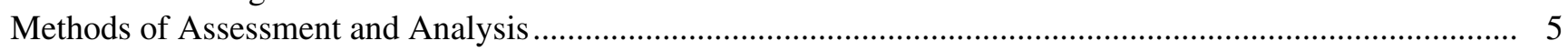

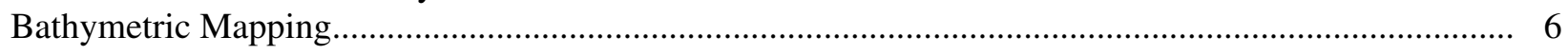

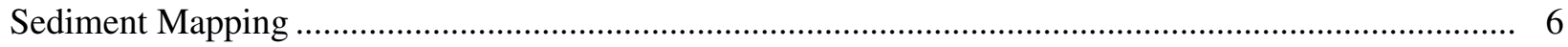

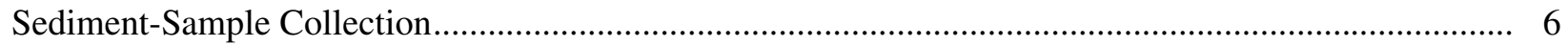

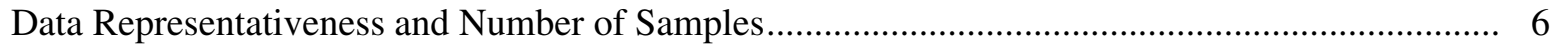

Collecting and Processing Samples ....................................................................................... 8

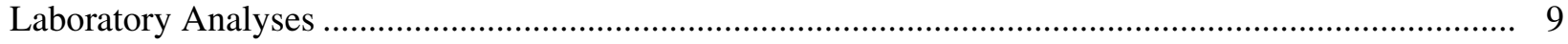

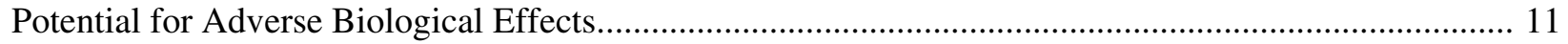

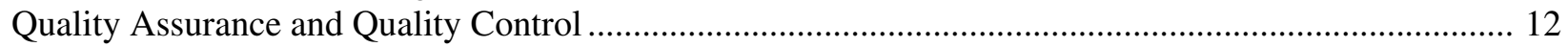

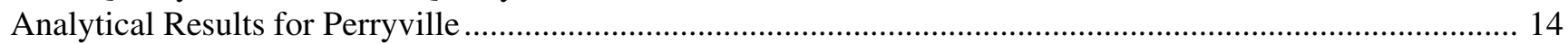

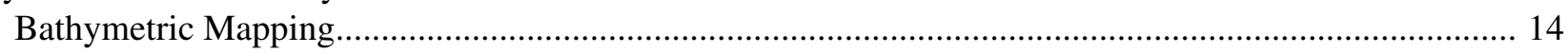

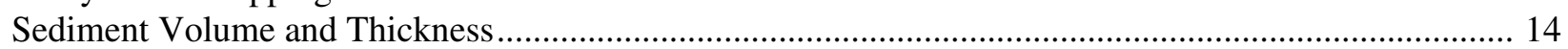

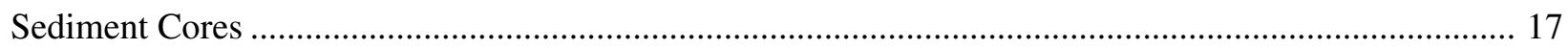

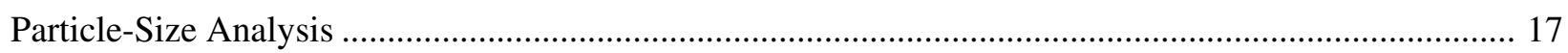

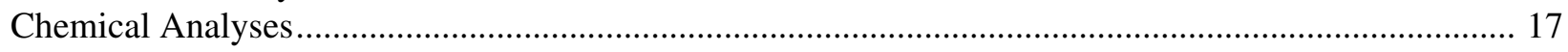

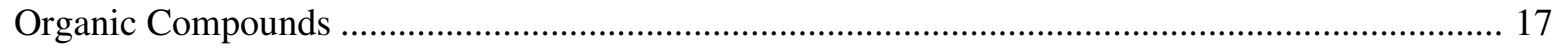

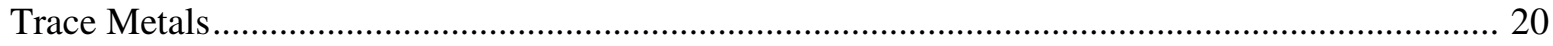

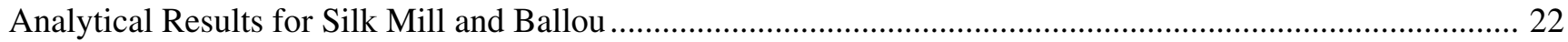

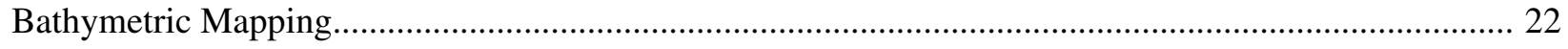

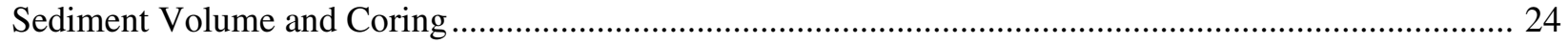

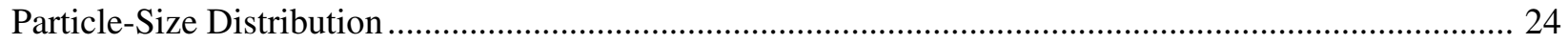

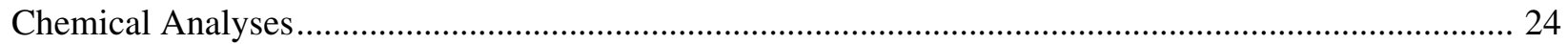

Application of Guidelines for Assessing Sediment Chemistry ............................................................... 24

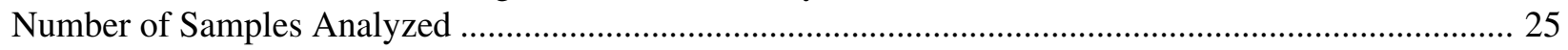

Contaminant Concentrations and Exceedance Guidelines............................................................ 25

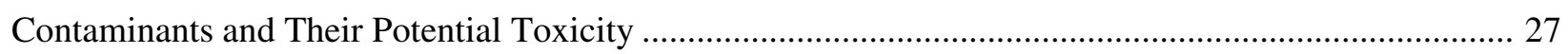

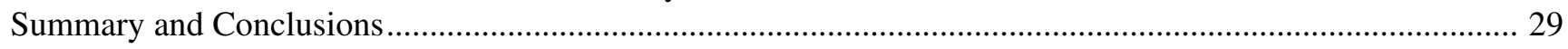

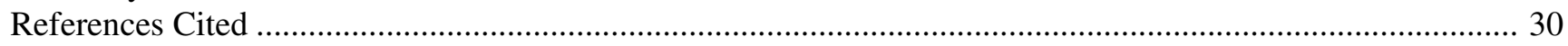

Appendix: Complete Listing of Elemental Analyses Performed by XRAL Laboratories, Inc.......................... 31 


\section{FIGURES}

Figure 1. Map showing locations of the Perryville Dam on the French River in Webster, Massachusetts, and the Silk Mill and Ballou Dams on Yokum Brook in Becket,

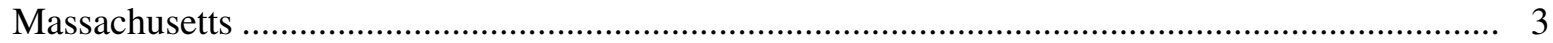

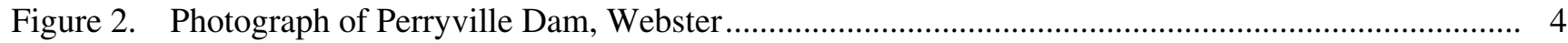

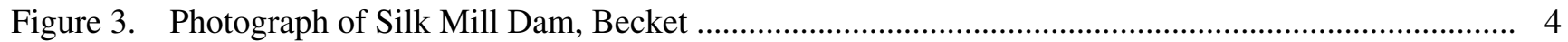

Figure 4. Photograph of Ballou Dam, Becket ..................................................................................... 5

Figure 5. Photograph showing ground-penetrating radar being used to collect field data............................ 7

Figure 6. Photograph of examination of a sediment core collected with a Livingstone corer from

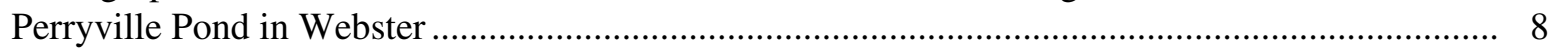

Figure 7. Photograph of centrally located island formed by sediment deposits and covered with purple loosestrife (Lythrum salicaria) in Perryville Pond in Webster............................................

Figure 8. Graph showing sediment-core lengths, depths below sediment surface, and samplesection identifiers 10

Figure 9. Map showing bathymetric and bottom-sediment thickness map of Perryville Pond in Webster 16

Figure 10. Map showing bathymetric and bottom-sediment thickness map of Silk Mill impoundment, Becket

Figure 11. Map showing bathymetric and bottom-sediment thickness map of Ballou impoundment, Becket 


\section{TABLES}

Table 1. Comparison of families of compounds that may be detected by the ELISA method used in this study in the U.S. Geological Survey Massachusetts-Rhode Island District laboratory and other methods used by Columbia Analytical Services, Inc., laboratory.

Table 2. Comparison of quality-control replicate samples analyzed by the ELISA method for organic compounds

Table 3. Comparison of ELISA results with duplicate quality-control sample results from

Columbia Analytical Sevices, Inc.

Table 4. Comparison of concentrations of selected metals in duplicate quality-control samples analyzed by XRAL Laboratories, Inc.

Table 5. U.S. Geological Survey sample identifiers and shortened identifiers for maps used in this study

Table 6. Sediment particle-size distribution for samples collected from Perryville Pond, Webster, and from Silk Mill and Ballou impoundments, Becket, Massachusetts, July 2000

Table 7. Results of ELISA analyses of organic sediment constituents in samples collected from Perryville Pond and from Silk Mill and Ballou impoundments

Table 8. Selected constituent concentrations in sediment samples from vegetated and open-water zones of Perryville Pond, 1984

Table 9. Concentrations of selected metals analyzed by XRAL Laboratories

Table 10. Number of samples needed to define the mean concentrations of analytes within 25 percent and with 90 percent confidence for Perryville Pond and the two Becket impoundments (Silk Mill and Ballou combined)

Table 11. Sediment-quality guidelines for freshwater benthic organisms and human-contact data 26

Table 12. Incidence of toxicity based on Probable Effect Concentration (PEC) quotients in samples from Perryville Pond, Silk Mill and Ballou impoundments 


\title{
CONVERSION FACTORS, ACRONYMS AND ABBREVIATIONS
}

\author{
CONVERSION FACTORS
}

\begin{tabular}{rll}
\hline Multiply & By & To Obtain \\
\hline cubic foot $\left(\mathrm{ft}^{3}\right)$ & 0.02832 & cubic meter \\
foot $(\mathrm{ft})$ & 0.3048 & meter \\
gram $(\mathrm{g})$ & 0.0353 & ounce, avoirdupois \\
inch (in) & 25.4 & millimeter \\
inch (in) & 2.54 & centimeter \\
inch (in) & 0.0254 & meter \\
microgram $(\mu \mathrm{g})$ & $3.53 \times 10^{-8}$ & ounce, avoirdupois \\
mile $(\mathrm{mi})$ & 1.609 & kilometer \\
milligram $(\mathrm{mg})$ & $3.53 \times 10^{-5}$ & ounce, avoirdupois \\
\hline
\end{tabular}

ACRONYMS AND ABBREVIATIONS

\begin{tabular}{|c|c|c|c|}
\hline ELISA & Enzyme-Linked Immunosorbent Assay & $\mathrm{Fe}$ & Iron \\
\hline GIS & Geographic Information System & $\mathrm{K}$ & Potassium \\
\hline GPR & Ground-Penetrating Radar & $\mathrm{Li}$ & Lithium \\
\hline GPS & global positioning system & $\mathrm{Mg}$ & Magnesium \\
\hline GSSI & Geophysical Survey Systems, Inc. & $\mathrm{Mn}$ & Manganese \\
\hline $\mathrm{mg} / \mathrm{kg}$ & milligram per kilogram & Mo & Molybdenum \\
\hline PAH & Polycyclic Aromatic Hydrocarbon & $\mathrm{Na}$ & Sodium \\
\hline PCB & Polychlorinated Biphenyl & $\mathrm{Ni}$ & Nickel \\
\hline $\mathrm{TPH}$ & Total Petroleum Hydrocarbon & $\mathrm{P}$ & Phosphorus \\
\hline$\mu \mathrm{g} / \mathrm{kg}$ & microgram per kilogram & $\mathrm{Pb}$ & Lead \\
\hline As & Arsenic & $\mathrm{Sb}$ & Antimony \\
\hline $\mathrm{Al}$ & Aluminum & $\mathrm{Sc}$ & Scandium \\
\hline $\mathrm{Ba}$ & Barium & $\mathrm{Sr}$ & Strontium \\
\hline $\mathrm{Be}$ & Beryllium & $\mathrm{Ti}$ & Titanium \\
\hline $\mathrm{Bi}$ & Bismuth & W & Tungsten \\
\hline $\mathrm{Ca}$ & Calcium & $\mathrm{Y}$ & Yttrium \\
\hline $\mathrm{Cd}$ & Cadmium & $\mathrm{Zn}$ & Zinc \\
\hline Co & Cobalt & & \\
\hline $\mathrm{Cr}$ & Chromium & & \\
\hline $\mathrm{Cu}$ & Copper & & \\
\hline
\end{tabular}




\title{
Sediment Quantity and Quality in Three Impoundments in Massachusetts
}

\author{
By Marc J. Zimmerman and Robert F. Breault
}

\section{ABSTRACT}

As part of a study with an overriding goal of providing information that would assist State and Federal agencies in developing screening protocols for managing sediments impounded behind dams that are potential candidates for removal, the U.S Geological Survey determined sediment quantity and quality at three locations: one on the French River and two on Yokum Brook, a tributary to the west branch of the Westfield River. Data collected with a global positioning system, a geographic information system, and sediment-thickness data aided in the creation of sediment maps and the calculation of sediment volumes at Perryville Pond on the French River in Webster, Massachusetts, and at the Silk Mill and Ballou Dams on Yokum Brook in Becket, Massachusetts. From these data the following sediment volumes were determined: Perryville Pond, 71,000 cubic yards, Silk Mill, 1,600 cubic yards, and Ballou, 800 cubic yards. Sediment characteristics were assessed in terms of grain size and concentrations of potentially hazardous organic compounds and metals.

Assessment of the approaches and methods used at study sites indicated that groundpenetrating radar produced data that were extremely difficult and time-consuming to interpret for the three study sites. Because of these difficulties, a steel probe was ultimately used to determine sediment depth and extent for inclusion in the sediment maps. Use of these methods showed that, where sampling sites were accessible, a machine-driven coring device would be preferable to the physically exhausting, manual sediment-coring methods used in this investigation. Enzyme-linked immunosorbent assays were an effective tool for screening large numbers of samples for a range of organic contaminant compounds. An example calculation of the number of samples needed to characterize mean concentrations of contaminants indicated that the number of samples collected for most analytes was adequate; however, additional analyses for lead, copper, silver, arsenic, total petroleum hydrocarbons, and chlordane are needed to meet the criteria determined from the calculations.

Particle-size analysis did not reveal a clear spatial distribution pattern at Perryville Pond. On average, less than 65 percent of each sample was greater in size than very fine sand. The sample with the highest percentage of clay-sized particles (24.3 percent) was collected just upstream from the dam and generally had the highest concentrations of contaminants determined here. In contrast, more than 90 percent of the sediment samples in the Becket impoundments had grain sizes larger than very fine sand; as determined by direct observation, rocks, cobbles, and boulders constituted a substantial amount of the material impounded at Becket. In general, the highest percentages of the finest particles, clays, occurred in association with the highest concentrations of contaminants.

Enzyme-linked immunosorbent assays of the Perryville samples showed the widespread presence of petroleum hydrocarbons (16 out of 26 samples), polycyclic aromatic hydrocarbons 
(23 out of 26 samples), and chlordane (18 out of 26 samples); polychlorinated biphenyls were detected in five samples from four locations. Neither petroleum hydrocarbons nor polychlorinated biphenyls were detected at Becket, and chlordane was detected in only one sample. All 14 Becket samples contained polycyclic aromatic hydrocarbons. Replicate quality-control analyses revealed consistent results between paired samples.

Samples from throughout Perryville Pond contained a number of metals at potentially toxic concentrations. These metals included arsenic, cadmium, copper, lead, nickel, and zinc. At Becket, no metals were found in elevated concentrations.

In general, most of the concentrations of organic compounds and metals detected in Perryville Pond exceeded standards for benthic organisms, but only rarely exceeded standards for human contact. The most highly contaminated samples were collected from sites at the upstream and downstream ends of Perryville Pond.

To estimate the potential toxicity of the sediment samples to invertebrates on the basis of their concentrations of metals and organic contaminants, consensus-based sediment-toxicity guidelines were applied. The results of the calculations based on these guidelines highlighted the locations of potentially toxic contaminant "hot spots" in Perryville Pond. Interpretation of sample data from the Becket impoundments did not indicate the existence of similar pockets of potentially toxic contamination.

\section{INTRODUCTION}

Massachusetts has more than 3,000 dams, 85 percent of which are over 50 years old. Many of these old dams are in hazardous states of abandonment and disrepair-conditions that are driving development of new approaches to management of the dams and the associated water resources. The primary options typically considered are dam removal or repair. A major issue with either of these options is the disposition of sediment that may have accumulated in the impoundments over decades or centuries. It may be necessary to redistribute or remove the impounded sediments to prevent or mitigate serious adverse effects downstream from the removal or repair of the dam. Redistribution of sediments through natural hydrodynamic processes after dam removal would minimize the associated costs. Existing physical and chemical data rarely suffice, however, for regulatory agencies to evaluate alternative options for sediment management, including natural redistribution and physical removal of sediments. Thus, a need exists for sampling protocols and screening methods to evaluate potential alternative options for management of impounded sediments.

The U.S. Geological Survey (USGS) evaluated sites visited by the River Restore Triage Team, under the auspices of the Riverways Program of the Massachusetts Department of Fisheries, Wildlife, and Environmental Law Enforcement, at Perryville Pond on the French River in the town of Webster, MA, and at the Silk Mill and Ballou impoundments on Yokum Brook, a tributary to the west branch of the Westfield River at Becket, MA (fig. 1). The hazardous condition of the Perryville Dam (fig. 2) has been a concern for a number of years. Its location, less than one-quarter mile from the Connecticut State line, and potential for failure and the subsequent uncontrolled release of potentially hazardous sediments, have made it an interstate issue. In Becket, the Silk Mill Dam (fig. 3) is filled with rocks, cobble, boulders, and sediment, and it is breached in several locations. The sediments at the bottom of the pond behind the Ballou Dam (fig. 4), which serves as a fire pond for the town, have displaced a large percentage of its water volume. Both of the dams in Becket impede the migration and spawning of Atlantic salmon (Salmo salar) from the Connecticut River.

\section{Previous Studies and Historical Information}

In 1987, the U.S. Environmental Protection Agency (USEPA) issued an Environmental Impact Statement (EIS) that listed several options for improving the French River's water quality (U.S. Environmental Protection Agency, 1987). The USEPA report included relevant data from previous studies and maps describing sediment distribution in Perryville Pond and other impoundments along the French River. 


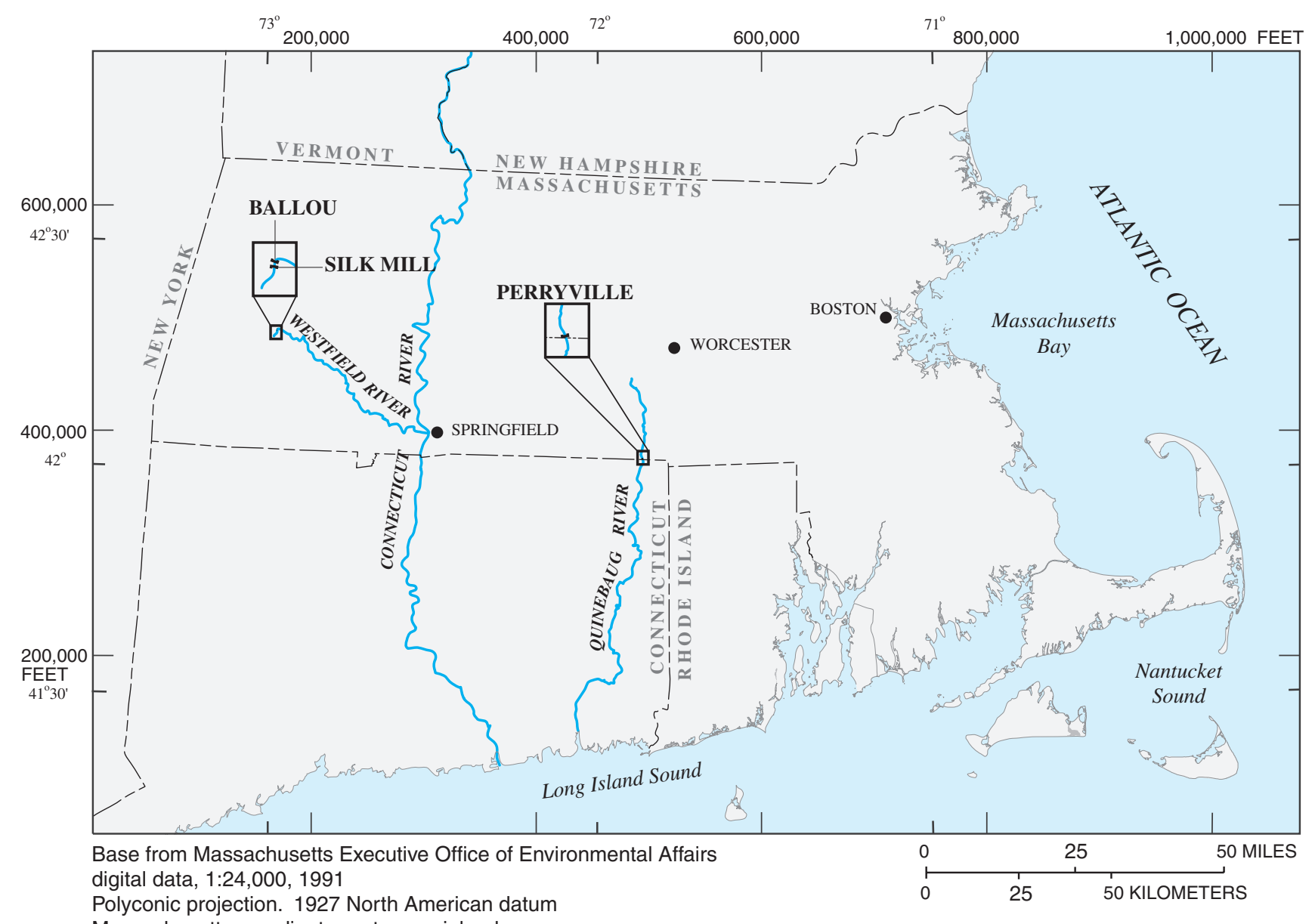

Figure 1. Locations of the Perryville Dam on the French River in Webster, Massachusetts, and the Silk Mill and Ballou Dams on Yokum Brook in Becket, Massachusetts.

According to the EIS, an earlier report had estimated the total volume of sediment in Perryville Pond as 63,000 cubic yards.

A review of all relevant information for the watershed (called a due-diligence review) provided additional background information on possible sources of contamination. Review of documents describing results of environmental consultants' studies in the watershed upstream from Perryville Pond gave further credence to the information in the USEPA (1987) report that noted high concentrations of heavy metals and organic contaminants-legacies of the basin's industrial history. In Becket, the local historical commission indicated that the area upstream of both dams had supported mills at some time in the past. The commission also provided documents describing a flood in the 1920s that would have displaced any impounded sediments from behind the Silk Mill Dam.
Further discussions with local officials revealed that sediments had been dredged from the Ballou impoundment approximately 15 years before this study. Thus, contaminants deposited before the 1920s at the Silk Mill Dam and before the mid-1980s at the Ballou Dam are no longer likely present.

\section{Purpose and Scope}

This report documents and evaluates sedimentscreening procedures used in this study for rapid and inexpensive surveys of sediment quantity and quality at three potential dam-removal projects in Massachusetts with the objective of providing regulatory agencies information needed to develop sediment-sampling protocols. The report details and presents interpretations of the results of grain-size, 


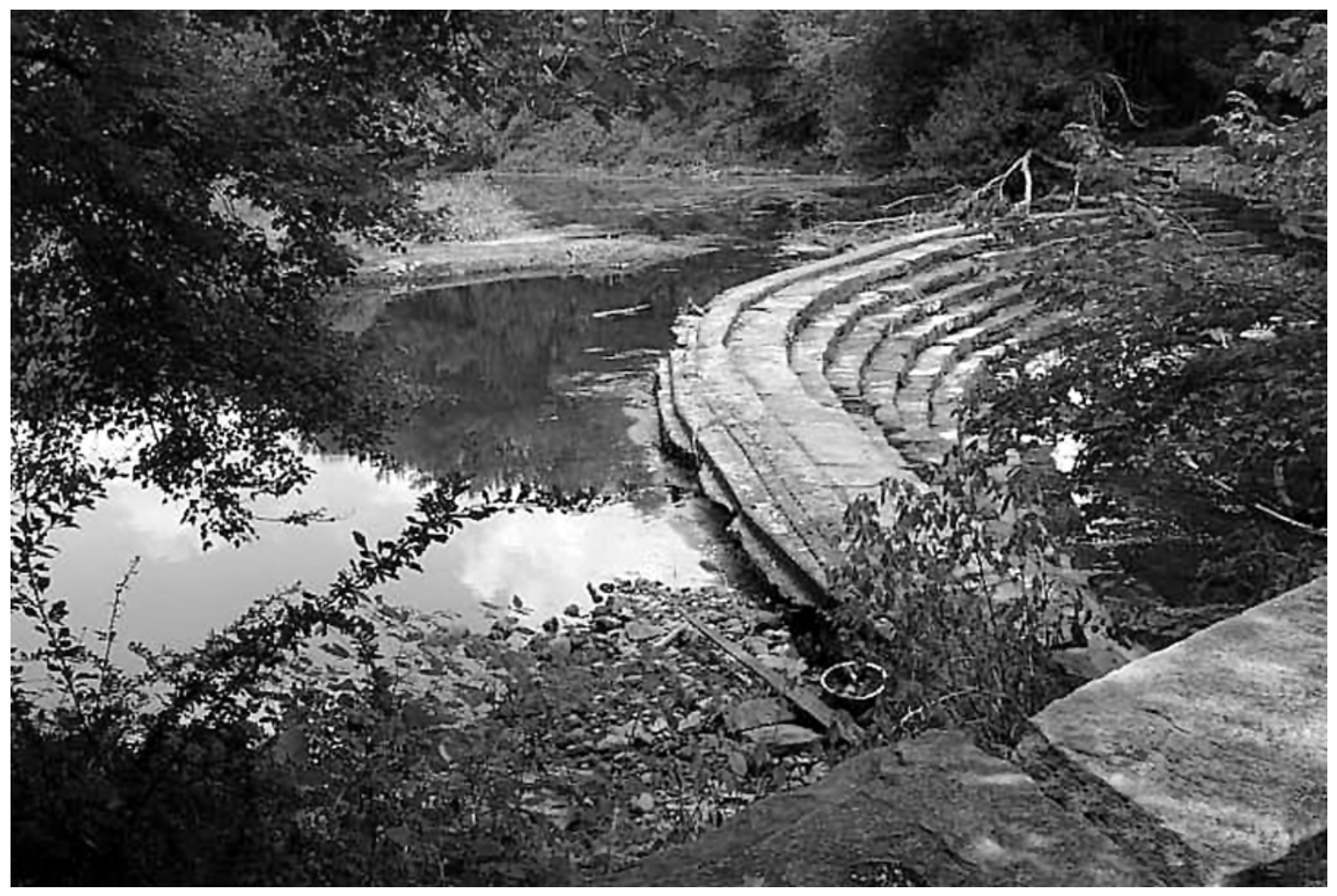

Figure 2. Perryville Dam, Webster, Massachusetts.

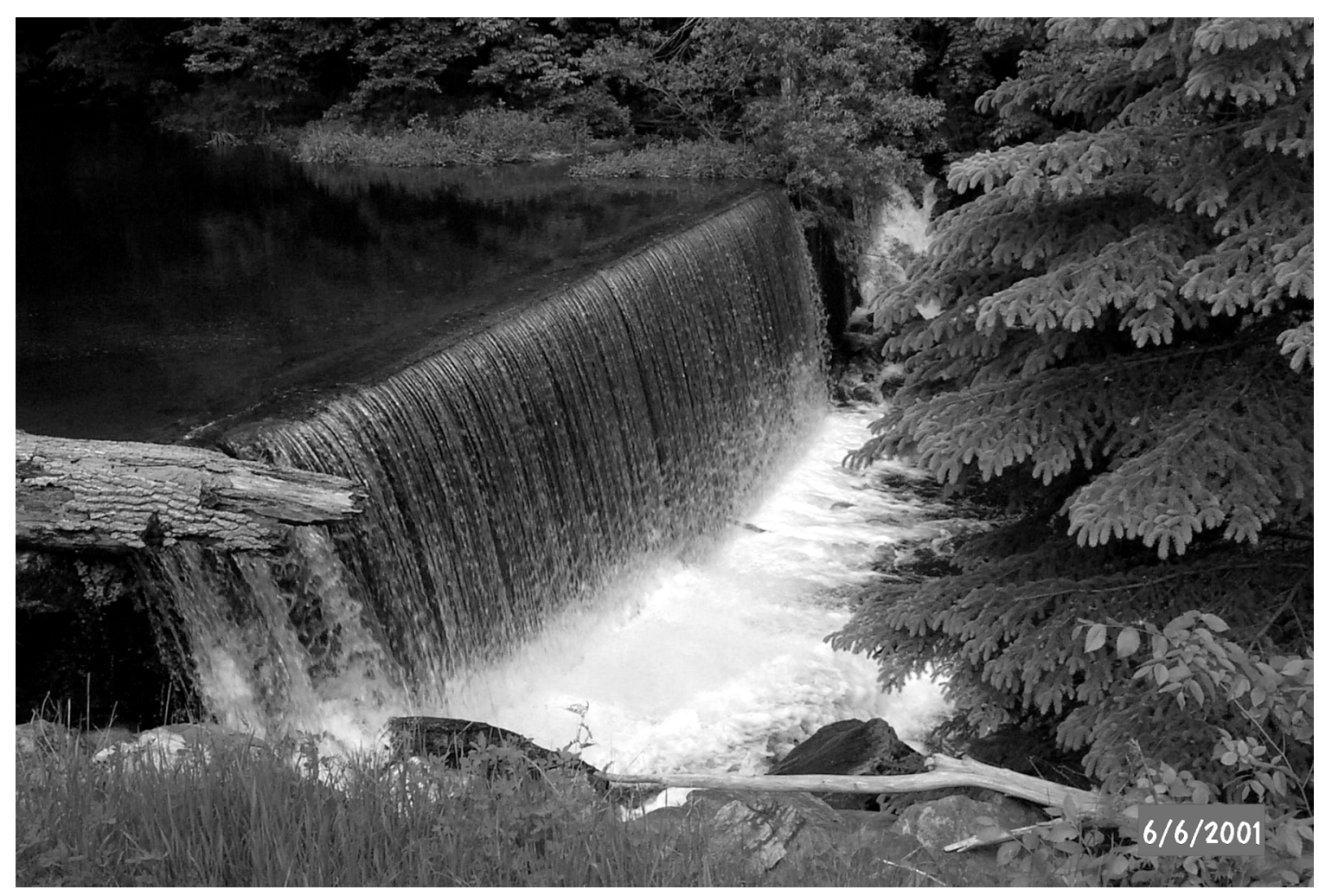

Figure 3. Silk Mill Dam, Becket, Massachusetts. 


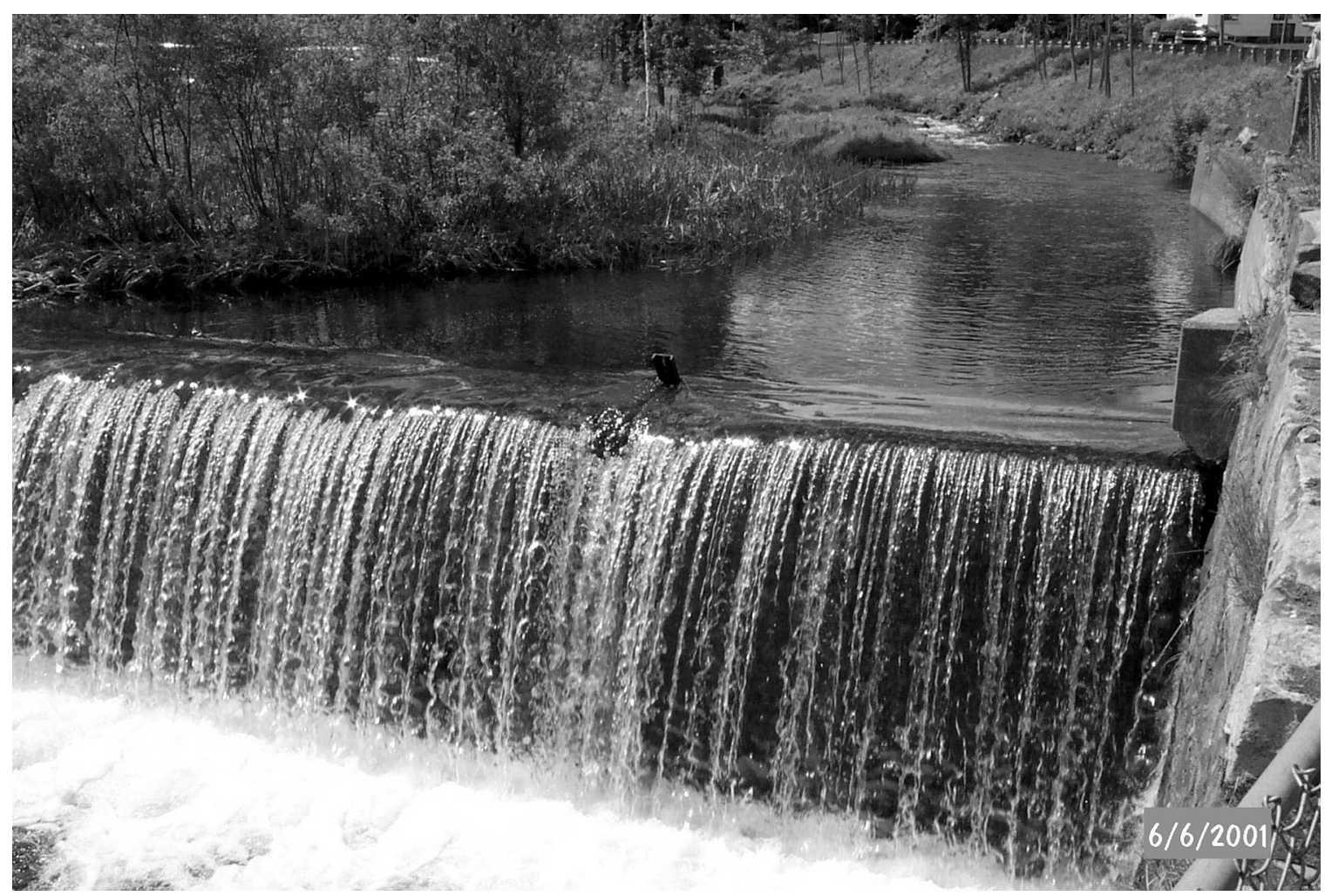

Figure 4. Ballou Dam, Becket, Massachusetts. Sediment-deposition island appears immediately upstream from the dam on the left side of the photograph.

elemental, and organic-chemical analyses, and offers suggestions as to how future studies may benefit from improved approaches. The major groups of chemical analytes include metals, total polychlorinated biphenyls (PCBs), total polycyclic aromatic hydrocarbons (total PAHs), total petroleum hydrocarbons (TPHs), and total chlordane. This report also describes the areal extent of sediments deposited in the three impoundments and provides calculations of the sediment volumes.

\section{Acknowledgments}

The authors express their thanks to several people whose support and encouragement were important factors in this project's success. We especially appreciate the enthusiasm of Karen Pelto, Massachusetts Department of Fisheries, Wildlife, and Environmental Law Enforcement, River Restore Program coordinator in the Massachusetts Executive Office of Environmental Affairs, in promoting this project and in obtaining its funding. Jacqueline Gillis, Harvard University, volunteered her professional expertise and many hours of her time to help us organize and prepare samples for analysis. This study also benefitted from the assistance of USGS colleagues Peter Joesten, Geophysicist, Storrs, CT; Britt Stock, Hydrologic Technician, Northborough, MA; Jason R. Sorenson and Marcus C. Waldron, Hydrologists, Northborough, MA; and James Degnan, Hydrologist, Pembroke, NH. Technical reviews by Leslie A. DeSimone, USGS, Northborough, MA; and Matt Liebmann, USEPA, Boston, MA, substantially improved the report's final version.

\section{METHODS OF ASSESSMENT AND ANALYSIS}

For this study, bathymetry and sediments were mapped at each of the three sites. Sediment samples were collected to provide data that accurately represented physical properties and chemical concentrations of sediments. Samples were analyzed at the Iowa and Massachusetts-Rhode Island District laboratories, and at the XRAL laboratories, Ontario, 
Canada. The potential toxicity of all contaminants found in the samples was also analyzed. Qualitycontrol samples were collected and analyzed in the USGS Massachusetts-Rhode Island District laboratory and in the Columbia Analytical Services (CAS), Inc., laboratory, Kelso, Washington.

\section{Bathymetric Mapping}

Manually probing with a a steel rod determined water depths. Field reconnaissance of the study areas helped delineate land/water interfaces and water depths in the impoundments. Measurements totalled approximately 50 points in the Perryville and Silk Mill impoundments and about 40 points in the Ballou impoundment. The triangular irregular network (TIN) data model and topogrid function of the Environmental Systems Research Institute's ARC/INFO GIS software were used to generate bathymetric maps. Collecting additional field data would have made easier the computerized mapping process for both bathymetry and sediment extent.

\section{Sediment Mapping}

Initially, ground-penetrating radar (GPR) and a global positioning system (GPS) were used to determine sediment depth and extent. Later, probing with a steel rod replaced the use of GPR to determine sediment thickness to the point of refusal in the river bottom at Perryville and Becket. During the GPR component of the study, a GSSI (Geophysical Survey Systems, Inc.) SIR-10+ system with a 100-Megahertz transmitter and receiver and a Trimble GPS with submeter accuracy were used to provide data for interpretation.

GPR systems emit short pulses of electromagnetic energy from a transmitting antenna. The energy enters the material (in this study, the water column and bottom sediments in the impoundment) and passes through the material until it reaches an interface between materials (such as sediment/water and sediment/bedrock) with different dielectric constants. These interfaces reflect some of the energy that a surface receiver antenna subsequently detects; a computer then records the traveltime and strength of the signal. Interpretation of traveltimes from graphical
GPR records, along with estimated radar-wave velocities for the different materials provides the basis for calculating bottom-sediment thicknesses.

Aquatic vegetation does not hinder the use of GPR, which can work effectively in water as shallow as 6 in. In this study, the GPR recording equipment was either carried in a boat while towing the antennae (fig. 5) or left on the shore while the antennae were dragged across land surfaces.

Initial attempts were made to use GSSI RADAN software to interpret sediment thickness and waterdepth data from field recorders and from GIS software to develop sediment maps and determine sediment volumes. First, the GPS data were matched with existing topographic data from a geographic information system (GIS) to create maps depicting the trajectories traversed with the GPR unit. Multiple reflective surfaces, such as boulders, ledges, and clay layers that yielded ambiguous results, however, made it too difficult to confidently interpret sediment depths at specific locations in the GPR datasets. Finally, the Environmental Research Institute's TIN and ARC/INFO GIS software generated the sediment maps and calculated sediment volume on the basis of data from manual probing.

\section{Sediment-Sample Collection}

One objective of this study was to provide data that accurately represented the existing physical properties and chemical concentrations of sediment in the sampled system in order to guide sedimentmanagement decisions with respect to dam removal. In collecting samples to meet this objective, different types of core samplers were used. Samples were processed either in the field immediately after collection, or shortly afterward in the MassachusettsRhode Island District laboratory.

Data Representativeness and Number of Samples

Because this was a screening-level study, its scope (in terms of number of samples and analytes) was limited by design and budget. In order for informed management decisions to be made on the basis of these data, it is worthwhile to assess whether the goal of providing accurate representations of the system with a limited number of samples was achieved. 


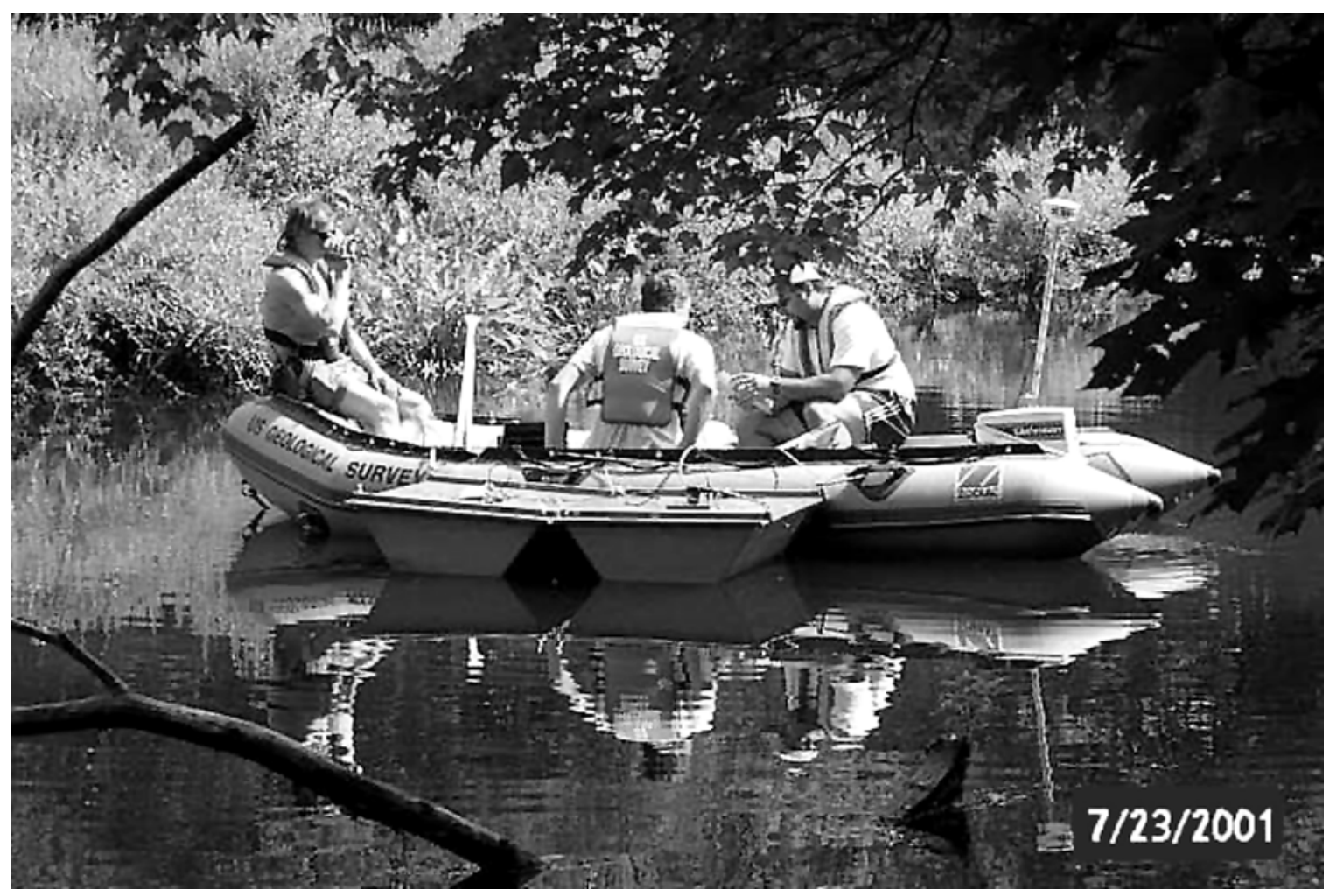

Figure 5. Ground-penetrating radar being used to collect field data.

In other words, were enough data collected to determine a representative value (for example, the mean) for any given sedimentological parameter or constituent concentration and, if not, how many additional samples would be needed?

Determining the appropriate number of samples needed to characterize the sediment quality at a potential dam-removal site calls for a two-stage approach. First, best scientific judgment (informed by the due-diligence survey) should guide the collection of sediment samples from spatially representative areas. Considerations include the locations of depositional environments and suspected or known contaminant sources, maximum sediment thickness, and location of fine particulates. In this study, the significant depositional zones emerged above the water surface. The initial number of samples should be chosen to capture the variability of the sediment chemistry both in terms of areal distribution and actual concentrations; if additional sampling is called for, the important locations and analytes will be known. Second, if the data are normally distributed, then the number of samples required to approximate a target statistic, for example, the true mean (eq. 1), can be calculated for a specific confidence level; that is, the number of sediment samples needed to describe "contamination" accurately depends on the degree of precision required.

The number of samples needed to determine the mean value (or some other measure of central tendency) can be estimated from the sediment screening data and simple statistics:

$$
N_{i}=\left(t_{c} \times S_{x, i} / y \times \bar{x}_{i}\right)^{2}+1
$$

where

$N_{i}$ is the number of data (or samples) for parameter or constituent $i ; t_{c}$ is the value of student's $t$ for desired two-sided confidence interval $c$ with $n$ - 1 degrees of freedom, where $n$ is the number of samples; $s_{x, i}$ is the variance for parameter or constituent $i$ from the sediment-screening study; $\bar{x}_{i}$ is the average concentration of parameter or constituent $i$ from the sediment-screening study; and $y$ is the acceptable error, in percentage of the mean (generally, 25-percent error is considered acceptable between laboratory 
duplicates; therefore, estimation of the mean within the limits of laboratory error, with a 90-percent confidence level, is reasonable. The equation is based on three assumptions: (1) the variability of the sedimentscreening data approximates the "true" variability in physical properties and chemical concentrations of sediment behind the dam, (2) sediment sampling techniques and analysis were adequate (for example, sampling techniques did not contaminate samples), and (3) physical and chemical data are approximately normally distributed (Hakanson, 1984). If the data are not normally distributed, alternative equations may be used to calculate the statistic (Kratochvil and Taylor, 1981).

In this study, a sufficient number of sampling sites was selected, on the basis of best scientific judgment, and in collaboration with State and Federal regulatory agencies, to provide a good representation of the distribution of contaminants in the impoundments. Limited time and budget also affected the number of samples that could be collected and analyzed.

\section{Collecting and Processing Samples}

Three types of manual sediment corers were used to collect sediment samples: (1) an Ogeechee sand corer (Wildlife Supply Company, Buffalo, NY), (2) a custom-made plexiglass piston corer, and (3) a Livingstone corer (a multi-section piston corer). Obtaining and retaining a sediment core in the coring device can pose common, major problems: first, a plug can form at the opening of the corer and prevent additional material from entering; second, coarse material or very dense clays can prevent the corer from fully penetrating sediments; and third, a sediment core may slip out of the corer during retrieval. The piston corers, particularly the Livingstone corer, proved most effective in recovering cores (for example, fig. 6) under the variety of conditions at these sites, as they minimized all of the above problems and produced the longest, continuous cores. The multi-section Livingstone corer also has a serrated cutting edge that enabled it to penetrate dense clay layers. The sand corer regularly became blocked by clay or failed to retain its samples when attempts were made to retrieve them. Finally, all three types of corers required substantial physical effort to drive into and extract from the sediments, either from a boat or from a river bank.

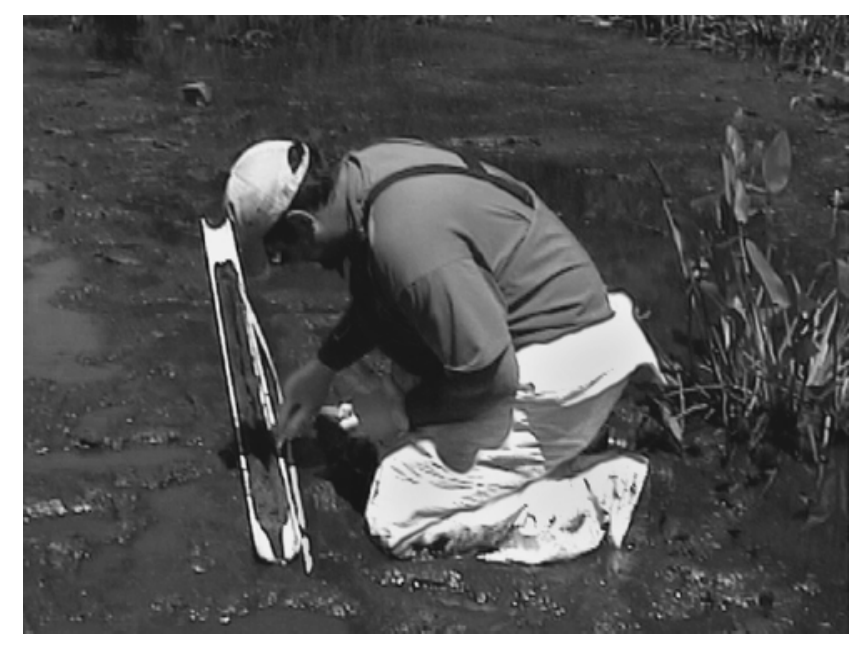

Figure 6. Examination of a sediment core collected with a Livingstone corer from Perryville Pond in Webster, Massachusetts.

In general, this investigation focused on areas likely to have fine-grained materials commonly associated with contaminants (Horowitz, 1991); furthermore, it was not feasible to sample coarse sediments with conventional equipment. Other sitespecific issues affected our ability to collect samples. In Perryville Pond, shallow water depths limited boat access to some areas, and purple loosestrife (Lythrum salicaria) infested by bumblebees covered others (fig. 7). At Becket, samples were collected from representative areas of these small impoundments; the coarse nature of the substrate, largely cobble and boulders, especially in the Silk Mill impoundment, made coring very difficult. Generally, the cores collected do not represent the complete sediment depth-a reflection of the difficulty of attempting to manually drive the corers.

Some of the samples were processed in the field immediately after collection, Afterwards, the corers were given thorough native-water rinses. In order to compare more recent deposits with older sediment deposits, cores were divided into subsections that yielded an 8-in-long sample representing the surface and at least one more sample taken from the deepest part of the core. Most cores were long enough to yield additional subsections representing middle regions of the core (fig. 8). (An alternative approach to collecting subsection samples might be to divide the core according to visual observations of changes in 


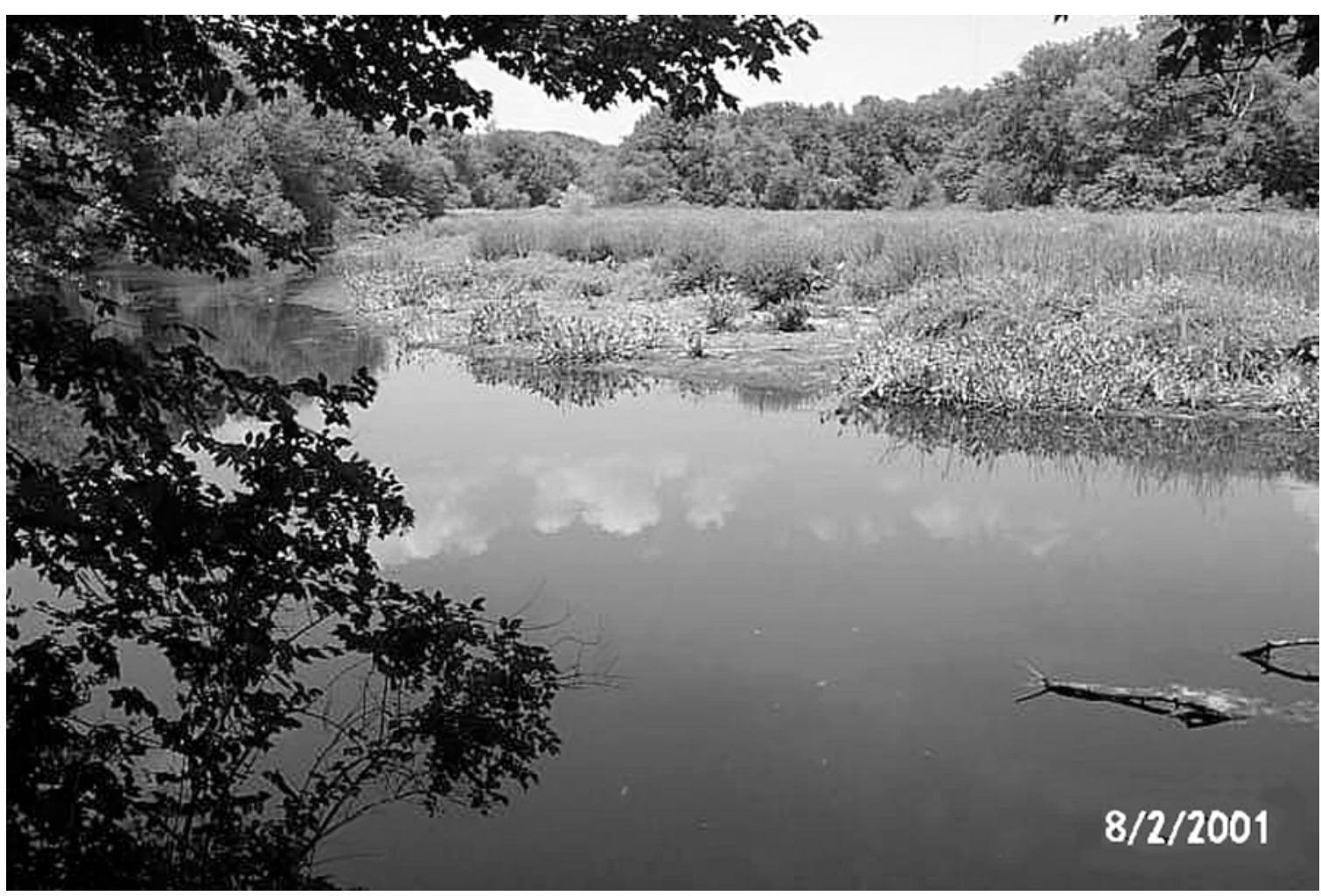

Figure 7. Centrally located island formed by sediment deposits and covered with purple loosestrife (Lythrum salicaria) in Perryville Pond in Webster, Massachusetts.

sediment appearance.) After sectioning a core, samples were homogenized with a stainless-steel spoon in a precleaned, stainless-steel bowl. Following about 5 minutes of homogenization, the samples were transferred to labelled, precleaned, quality-assured jars, and the jars were placed in sealed plastic bags and put into coolers containing ice. Cores that were not processed in the field were transported upright in coolers containing ice to the USGS MassachusettsRhode Island District Office laboratory, where the same sectioning and homogenization procedures used in the field were followed. Processed samples were transferred to a $4^{\circ} \mathrm{C}$ refrigerator for storage prior to analysis or to shipping to an outside laboratory. For shipment to outside laboratories, sediment subsamples were put into labelled Whirl-Pak plastic bags that were, in turn, put into plastic bags that were then sealed, placed in coolers containing ice, and shipped for overnight delivery.

\section{Laboratory Analyses}

The USGS Iowa District Sediment Laboratory performed the particle-size analyses. A three-point pipet method (Guy, 1969) was used to obtain a particlesize distribution for particles ranging from larger than very fine sand $(0.0625 \mathrm{~mm})$ to particles as small as clay (0.002 $\mathrm{mm}$ and less). For budgetary reasons, a full set of samples was not sent to the Iowa laboratory for particle-size analysis; overall, about two thirds of the samples were analyzed for particle-size distribution. Using USEPA Methods EPA 3050B for sample digestion and EPA 200.8 for analysis of low-level trace metals, XRAL Laboratories of Ontario, Canada, analyzed sediment samples for 30 elements, including the likely contaminants arsenic, cadmium, chromium, copper, lead, nickel, and zinc. XRAL used inductively coupled, plasma-emission spectroscopy to determine elemental concentrations. 


\section{A. PERRYVILLE CORE SECTIONS}

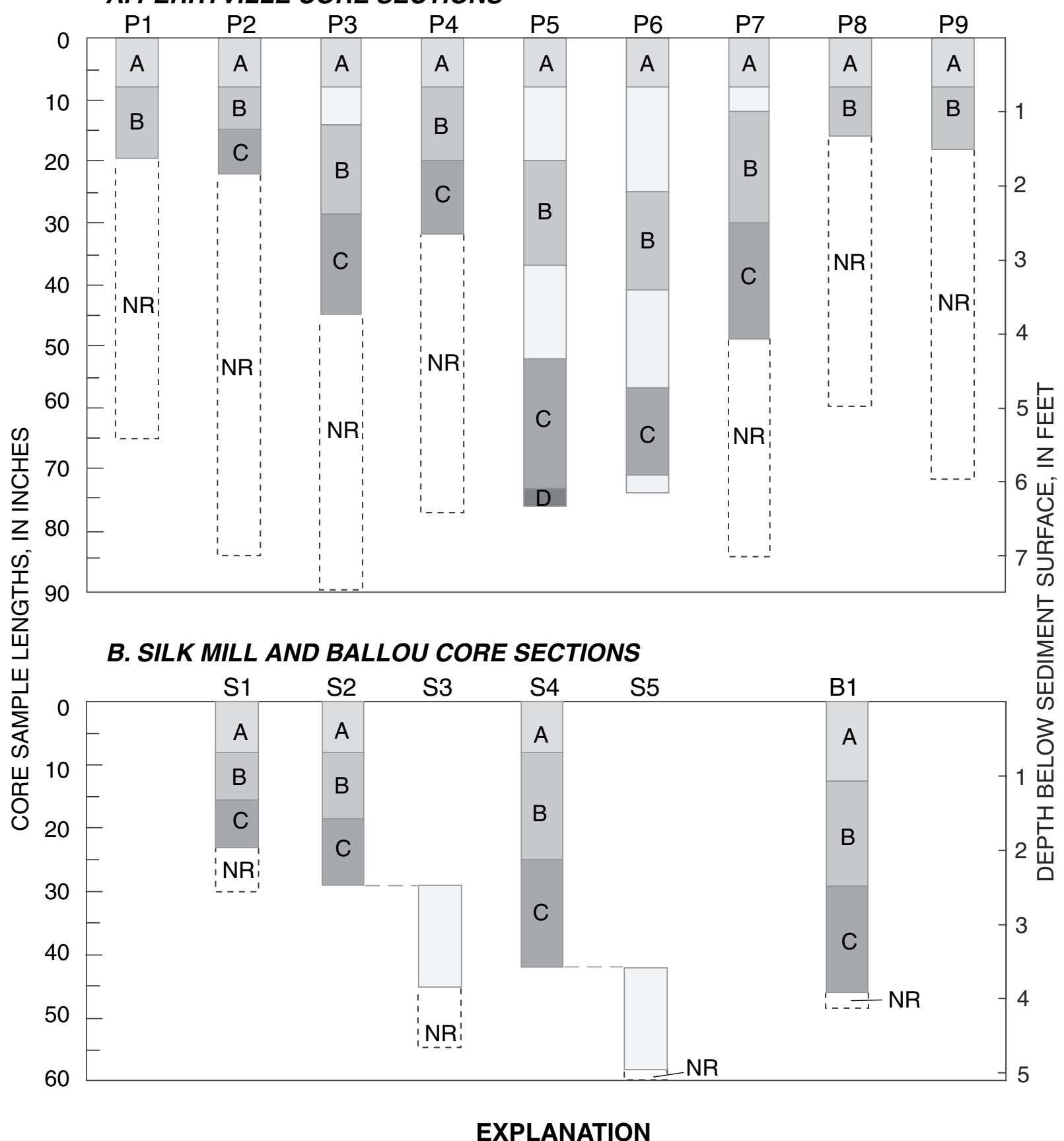

S1 CORE IDENTIFIERS-P, Perryville, S, Silk Mill, and B, Ballou. Letters $A, B, C$, and $D$ represent samples taken at various depths.

APPROXIMATE EXTENT OF SEDIMENT BELOW RECOVERED CORE-NR, No Recovery

Figure 8. Sediment-core lengths, depths below sediment surface, and sample-section identifiers. 
In the USGS Northborough laboratory, enzymelinked immunosorbent assays (ELISA) were used to analyze samples for total PAHs, TPHs (equivalent to a total BTEX $^{1}$ analysis), total PCBs, and chlordane (including other cyclodiene pesticides). The Department of the Interior is a partner agency in the Federal Remediation Technologies Roundtable, which has identified the ELISA techniques applied here as appropriate for a screening study of this nature. (Federal Remediation Technologies Roundtable, 2002). Federal agencies, including the U.S. Navy, the U.S. Army, and the USEPA also regularly apply immunoassays in Rapid Sediment Characterization studies (Kirtay and Apitz, 2000; U.S. Army Corps of Engineers, 2000; Kirtay, 2001). USGS investigators have also used immunoassays, primarily in studies of pesticides in water (Aga and others, 1994; Schulze and others, 1990). In order to simplify discussion in this report, the familiar terms PAHs, TPHs, PCBs, and chlordane refer to our analytical methods and results. The ELISA analysis uses a competitive reaction of a mixture of analyte and an enzyme-labeled analog of the analyte for a limited number of antibody binding sites (Gruessner and others, 1995). Color-producing reagents are added to the mixture and allowed to incubate. After the excess reagent is removed, the color of the mixture is measured with a spectrophotometer; the analyte concentration is inversely proportional to color intensity. This study used RaPID Assay and EviroGard test-kit supplies and equipment purchased from Strategic Diagnostics, Inc., Newark, DE.

The analysis of each sample required 10.0 $\pm 0.1 \mathrm{~g}$ of sediment. Furthermore, the sample had to consist of at least 70 percent solid material after dewatering (Karen Peluso, Strategic Diagnostics, Inc., oral commun., 2001). To prepare the samples for analysis, substantially more than $10.0 \mathrm{~g}$ of sediment were dried overnight at room temperature in a fume hood. Prior experimentation indicated that this procedure would result in evaporation yielding sample material meeting the 70-percent criterion.

\footnotetext{
${ }^{1}$ BTEX refers to the benzene, toluene, ethylbenzene, and xylene low-molecular-weight components of petroleum hydrocarbon mixtures.
}

After drying, $10.0 \pm 0.1 \mathrm{~g}$ of sediment were weighed and placed in bottles for extraction by methanol. A premeasured volume of methanol was added to each sample bottle, the lid was replaced, and the sample was shaken for 1 minute. After allowing the sample material to settle for several minutes, a prescribed aliquot was removed for analysis according to the specific procedures defined by the manufacturer for the various analytes.

In general, these methods allow an analyst to report results quantitatively. Concentrations less than the method's detection level, however, are reported as non-detects; and concentrations that exceeded the maximum calibration values are reported in tables as "greater than," which is denoted with the ">" symbol. From the raw data, it is still possible to compare relative magnitudes among "greater than" values. In one set of analyses for chlordane, a good blank reading was not obtained, so only semiquantitative results were produced for this set. To maintain consistency, all the chlordane data have been reported semiquantitatively; that is, the detections are reported within a range of concentrations.

\section{Potential for Adverse Biological Effects}

In addition to the frequency with which contaminant concentrations exceeded specific, contaminant criteria, the potential toxicity of all the contaminants in sediment samples was estimated on the basis of consensus-based sediment-quality guidelines (U.S. Environmental Protection Agency, 2000b.) This method of interpretation effectively assesses the management option of natural, hydrologic redistribution, or "no-action"; that is, the likely effect of leaving the sediments in place. These guidelines can be applied not just to individual contaminants, but also to a suite of metals and compounds to estimate their combined toxic effects. The environmental-sample concentration is divided by the probable effect concentration (PEC), the concentration above which, according to the consensus-based sediment-quality guidelines, adverse effects on benthic organisms are expected; the resulting value is called a PEC quotient. Then, in the application used here, the PEC quotients for each sample are averaged within their respective groups: metals, PAH, and PCB. The mean of the three group values is then determined. This average value, referred to as the Mean MPP (for Metal, PAH, and 
PCB), represents an equal weighting of the three contaminant groups. Additional groups of contaminants can be included, if adequate data are available. Finally, the Mean MPPs are compared to values associated with sediments of known toxicity to such standard test organisms as the amphipod Hyalella azteca, or the insect larva Chironomus sp. Thus, this approach offers a means of estimating the toxicity of a given sediment sample without actually performing the toxicity tests.

Preparation of the data for the Mean MPP calculations followed procedures described by the USEPA (2000b). For environmental-sample concentrations lower than the reporting limit, the values were set to one half of the reporting limit. For values exceeding the maximum level of quantitation, the values were set to the maximum level of quantitation. For semiquantitative results reporting concentrations within a range of values, the sample concentrations were set to the midpoint of the range; for example, if the reported concentration was between 100 and 600 , then a value of 350 was used.

\section{Quality Assurance and Quality Control}

In addition to the quality-control (QC) samples analyzed in the Massachusetts-Rhode Island laboratory for organic constituents, 12 samples were sent to CAS for outside corroboration. CAS also performs its own internal QC analytical procedures. CAS's analytical methods differ from those used in the Massachusetts-Rhode Island laboratory (table 1); but to validate the approach using ELISA, methods were selected in consultation with CAS Project Chemist Ed Wallace (oral commun., 2001), to yield comparable results. Because the ultimate disposition of contaminated sediments, as determined by regulatory agencies, would depend on the presence of specific compounds, interest focused on confirming that the ELISA method would yield neither false positive nor false negative results for the classes of compounds considered. However, James Eberts (Strategic Diagnostics, Inc., oral commun., 2002) indicates that to meet regulatory applications, the ELISA methodology is designed to minimize the possibility of false negatives and may yield positively biased results; that is, with a screening approach intended to identify sites with elevated contaminant concentrations for additional evaluation and potentially for eventual remediation, it is preferable to overestimate concentrations slightly.

ELISA analyses provide total concentrations for a group of compounds (table 1), because each specific antibody has a different affinity for each member of the group; the analyses are calibrated for a specific compound. Thus, ELISA results are reported as "totals." On the other hand, the chromatographic methods used by CAS yield data on each individual compound. For example, ELISA total PCB analyses yield a single value, whereas CAS provided the concentrations of seven individual PCB congeners (USEPA method 8081) that were summed to yield total concentrations. To compare them with our EnviroGard chlordane results, total chlordane concentrations were obtained by summing individual CAS organochlorinepesticide analyses. For comparison with our ELISA TPH and total PAH analyses, CAS provided oil-andgrease and PAH analyses (USEPA methods $1664 \mathrm{M}$ and 8310), respectively. According to the USEPA (2000a), the oil-and-grease method may yield the same quantitative results as TPH analyses, but should not necessarily be expected to do so. The oil-and-grease method does not yield data on individual compounds.

The internal QC-duplicate analyses for samples analyzed by ELISA show some variability within analyte groups (table 2). The results are consistent and do indicate the general magnitude of the analyte concentrations. Despite the different methods of preparation and analysis between ELISA and CAS, a comparison of their results (table 3 ) further supports the usefulness of the ELISA methods as screening tools: only 2 of the 15 comparisons do not match in terms of detection compared to non-detection, and these disparities are both at the low ends of the concentration ranges for the methods that gave the detections (ELISA chlordane and CAS oil and grease). Although the samples were manually homogenized for 5 minutes, it is possible that inhomogeneities remained that would have contributed to variability in the results, especially considering the small amount of material needed for an analysis. Matrix interference may also contribute to analytical variability. 
Table 1. Comparison of families of compounds that may be detected by the ELISA method used in this study in the U.S. Geological Survey Massachusetts-Rhode Island District laboratory and other methods used by Columbia Analytical Services, Inc., laboratory

[CAS, Columbia Analytical Services, Inc.; ELISA, Enzyme-Linked Immunosorbent Assay; EPA 4035, EPA 4041, EPA 4020, EPA 3550 B, EPA 8082, EPA 8081A, U.S. Environmental Protection Agency methods; PAH, polycyclic aromatic hydrocarbon; PCB, polychlorinated biphenyl; TPH, total petroleum hydrocarbon]

\begin{tabular}{|c|c|c|c|}
\hline ELISA & CAS & ELISA & CAS \\
\hline PAH (EPA 4035) & PAH (EPA 3550B) & PCB (EPA 4020) & PCB (EPA 8082) \\
\hline Phenanthrene & Phenanthrene & Aroclor 1254 & Aroclor 1254 \\
\hline Fluoranthrene & Fluoranthrene & Aroclor 1260 & Aroclor 1260 \\
\hline $\operatorname{Benzo}(a)$ pyrene & $\operatorname{Benzo}(a)$ pyrene & Aroclor 1248 & Aroclor 1248 \\
\hline Pyrene & Pyrene & Aroclor 1242 & Aroclor 1242 \\
\hline Chrysene & Chrysene & Aroclor 1262 & \\
\hline Anthracene & Anthracene & Aroclor 1232 & Aroclor 1232 \\
\hline Indeno(1,2,3-cd)pyrene & Indeno( $1,2,3-c d)$ pyrene & Aroclor 1268 & \\
\hline $\operatorname{Benzo}(b)$ fluoranethrene & $\operatorname{Benzo}(b)$ fluoranethrene & Aroclor 1016 & Aroclor 1016 \\
\hline Acenaphthylene & Acenaphthylene & Aroclor 1221 & Aroclor 1221 \\
\hline $\begin{array}{l}\operatorname{Benzo}(k) \text { fluoranthrene } \\
\text { Acenaphthalene }\end{array}$ & $\begin{array}{l}\operatorname{Benzo}(k) \text { fluoranthrene } \\
\text { Acenaphthene }\end{array}$ & Chlordane (EPA 4041) & $\begin{array}{l}\text { Organochlorine Pesticides } \\
\text { (EPA 8081A) }\end{array}$ \\
\hline $\operatorname{Benzo}(g, h, i)$ perylene & $\operatorname{Benz}(a)$ anthracene & Chlordane & Alpha-Chlordane \\
\hline Naphthalene & Naphthalene & & Gamma-Chlordane \\
\hline \multirow[t]{2}{*}{ Dibenzo $(a, h)$ anthracene } & $\operatorname{Dibenzo}(a, h)$ anthracene & Endosulfan I & Endosulfan I \\
\hline & Fluorene & Endosulfan II & Endosulfan II \\
\hline TPH & Oil and Grease (EPA 1664M, & Dieldrin & Dieldrin \\
\hline Total BTEX & Non-Polar Material) & Alpha-BHC & Alpha-BHC \\
\hline$m$-Xylene & & Gamma-BHC & Beta-BHC \\
\hline$p$-Xylene & & Delta-BHC & Delta-BHC \\
\hline Ethylenzene & & Heptachlor & Heptachlor \\
\hline Toluene & & & Heptachor Epoxide \\
\hline Benzene & & Aldrin & Aldrin \\
\hline Naphthalene & & Toxaphene & Toxaphene \\
\hline 1,2,4-Trimethylbenzene & & Endrin & Endrin \\
\hline Anthracene & & & Endrin Aldehyde \\
\hline Styrene & & & Endrin Ketone \\
\hline Hexachlorobenzene & & & Endosulfan Sulfate \\
\hline Phenanthrene & & & Methoxychlor \\
\hline Creosote & & & 4,4'-DDT \\
\hline 1,3,5-Trimethylbenzene & & & 4,4'-DDE \\
\hline Acenapthene & & & 4,4'-DDD \\
\hline \multicolumn{4}{|l|}{$n$-Propylbenzene } \\
\hline \multicolumn{4}{|l|}{$n$-Hexane } \\
\hline \multicolumn{4}{|l|}{$n$-Octane } \\
\hline \multicolumn{4}{|l|}{$n$-Nonane } \\
\hline \multicolumn{4}{|l|}{$n$-Heptane } \\
\hline \multicolumn{4}{|l|}{ Cyclohexane } \\
\hline \multicolumn{4}{|l|}{$n$-Decane } \\
\hline \multicolumn{4}{|l|}{ Methylene Chloride } \\
\hline Trichloroethylene & & & \\
\hline
\end{tabular}


Table 2. Comparison of quality-control replicate samples analyzed by the ELISA method for organic compounds

[Samples analyzed at the U.S. Geological Survey Massachusetts-Rhode Island District laboratory. PAH, polycyclic aromatic hydrocarbon; PCB, polychlorinated biphenyl; TPH, total petroleum hydrocarbon; $\mathrm{mg} / \mathrm{kg}$, milligrams per kilogram; $\mu \mathrm{g} / \mathrm{kg}$ micrograms per kilogram; $\mathrm{Q}$, indicates replicate quality-control sample; $>$, actual value is greater than value shown; ,-- not detected]

\begin{tabular}{lcccr}
\hline $\begin{array}{c}\text { Sample } \\
\text { ID }\end{array}$ & $\begin{array}{c}\text { PAH } \\
(\boldsymbol{\mu} \mathbf{g} / \mathbf{k g})\end{array}$ & $\begin{array}{c}\text { TPH } \\
(\mathbf{m g} / \mathbf{k g})\end{array}$ & $\begin{array}{c}\text { PCB } \\
(\boldsymbol{\mu g} / \mathbf{k g})\end{array}$ & $\begin{array}{c}\text { Chlordane } \\
(\boldsymbol{\mu g} / \mathbf{k g})\end{array}$ \\
\hline P2A & $1,120.00$ & -- & -- & $20-100$ \\
P2A-Q & $1,470.00$ & -- & -- & -- \\
P4C & $>5,000$ & 14.80 & 540 & $>600$ \\
P4C-Q & $>5,000$ & 17.20 & 600 & $>600$ \\
P8B & $>5,000$ & 27.10 & 640 & $20-100$ \\
P8B-Q & $>5,000$ & 16.10 & 760 & $20-100$ \\
\hline
\end{tabular}

Table 3. Comparison of ELISA results with duplicate quality-control sample results from Columbia Analytical Sevices, Inc.

[ELISA, results of analyses from the U.S. Geological Survey Massachusetts-Rhode Island District laboratory. CAS, Columbia Analytical Services, Inc.; PAH, polycyclic aromatic hydrocarbon; PCB, polychlorinated biphenyl; TPH, total petroleum hydrocarbon; $\mathrm{mg} / \mathrm{kg}$, milligrams per kilogram; $\mu \mathrm{g} / \mathrm{kg}$, micrograms per kilogram; >, actual value is greater than value shown; --, not detected]

\begin{tabular}{ccc}
\hline Sample ID & ELISA & CAS \\
\hline & PAH $(\mu \mathbf{g} / \mathbf{k g})$ & 174 \\
P1B & $>5.00$ & 3.72 \\
P2A & 1.12 & 2.41 \\
S2B & 2.61 & .847 \\
S4A & 4.34 & 4.86 \\
B1C & $>5.00$ & \\
& TPH $(\mathbf{m g} / \mathbf{k g})$ & \\
P7B & 4 & 4,000 \\
P3C & -- & -- \\
S4A & -- & 510 \\
& & \\
P4C & PCB $(\mu \mathbf{g} / \mathbf{k g})$ & 560 \\
P7C & 540 & -- \\
S4A & -- & -- \\
& -- & -- \\
P4B & & \\
P5B & Chlordane $(\mu \mathbf{g} / \mathbf{k g})$ & - \\
S4A & $100-600$ & - \\
B1A & -- & \\
\hline
\end{tabular}

XRAL Laboratories analyzed four duplicate samples for metals; XRAL also performs its own internal QC blank- and standard-sample analyses. The results of the XRAL analyses, like the organic analyses, showed some variability (table 4, appendix). Replicate samples for analysis of particle-size distribution were not sent to the USGS Iowa Sediment Laboratory, but its internal QC procedures require the preparation of replicates for analysis (Guy, 1969), and the laboratory performed a single replicate analysis (sample P5C, table 5). A comparison of these two particle-size-distribution analyses showed good correspondence.

\section{ANALYTICAL RESULTS FOR PERRYVILLE}

The determinations of the bathymetry and the sediment distribution, and the sediment-volume calculations in the Perryville impoundment were based on interpretations of the data obtained by manually measuring water depths and probing the sediments (fig. 9). For simplicity's sake, brief, rather than full, USGS identifiers (table 5) will be used in discussions of specific samples and their locations.

\section{Bathymetric Mapping}

Perryville Pond is a broad, shallow basin with a maximum water depth of about $6.7 \mathrm{ft}$ at the times final depth measurements were made in June 2002. Depths ranged from about 2 to $4 \mathrm{ft}$ in the main channel areas and were generally greatest along the western edge of the impoundment.

\section{Sediment Volume and Thickness}

Study results show the distribution of sediment in Perryville Pond similar to that depicted in the USEPA (1987) EIS. Approximately 71,000 cubic yards of sediment still remain trapped behind the Perryville Dam. The USEPA report estimated the total sediment volume as 63,000 cubic yards, but the full extent of the area included in that estimate is unclear. 
Table 4. Comparison of concentrations of selected metals in duplicate quality-control samples analyzed by XRAL Laboratories, Inc.

[All concentrations in milligrams per kilogram; <, actual value is less than value shown]

\begin{tabular}{|c|c|c|c|c|c|c|}
\hline Sample & Arsenic & Cadmium & Copper & Lead & Nickel & Zinc \\
\hline \multirow[t]{2}{*}{ P8A } & 35 & 5 & 346 & 459 & 26 & 897 \\
\hline & 32 & 4 & 316 & 420 & 25 & 823 \\
\hline \multirow[t]{2}{*}{$\mathrm{P} 4 \mathrm{C}$} & 8 & 2 & 239 & 179 & 21 & 263 \\
\hline & 6 & 1 & 226 & 163 & 21 & 247 \\
\hline \multirow[t]{2}{*}{ P10 } & 59 & $<1$ & 44.9 & 72 & 15 & 75 \\
\hline & 59 & $<1$ & 44.2 & 67 & 16 & 74.6 \\
\hline \multirow[t]{2}{*}{ B1A } & $<3$ & $<1$ & 11.5 & 20 & 14 & 87 \\
\hline & $<3$ & $<1$ & 11.5 & 20 & 14 & 88.7 \\
\hline
\end{tabular}

Table 5. U.S. Geological Survey sample identifiers and shortened identifiers for maps used in this study

[Brief sample and map identifier: A brief format for use on maps and in discussions. The first letter identifies the impoundment (B, Ballou; P, Perryville; $\mathrm{S}$, Silk Mill). The number indicates the location in the impoundment. The final letter (A-F), if one, indicates the depth from which the sample was collected (see fig. 8). USGS, U.S. Geological Survey]

\begin{tabular}{|c|c|c|c|}
\hline $\begin{array}{l}\text { USGS location and } \\
\text { sample identifier }\end{array}$ & $\begin{array}{l}\text { Brief sample and } \\
\text { map identifier }\end{array}$ & $\begin{array}{l}\text { USGS location and } \\
\text { sample identifier }\end{array}$ & $\begin{array}{l}\text { Brief sample and } \\
\text { map identifier }\end{array}$ \\
\hline A3B-06-12.5 & B1A & D2B-03-41 & $\mathrm{P} 6 \mathrm{C}$ \\
\hline A3B-06-29.25 & B1B & D2B-03-57 & P6D \\
\hline A3B-06-46 & $\mathrm{B} 1 \mathrm{C}$ & D2B-03-71 & P6E \\
\hline A3B-07-8 & S1A & D2B-03-74 & $\mathrm{P} 6 \mathrm{~F}$ \\
\hline A3B-07-15.5 & S1B & D2B-04-8 & P7A \\
\hline A3B-07-23 & $\mathrm{S} 1 \mathrm{C}$ & D2B-04-12 & P7B \\
\hline A3B-08-8 & $\mathrm{S} 2 \mathrm{~A}$ & D2B-04-30 & $\mathrm{P} 7 \mathrm{C}$ \\
\hline A3B-08-18.5 & S2B & D2B-04-49 & P7D \\
\hline A3B-08-29 & $\mathrm{S} 2 \mathrm{C}$ & D2B-05-8 & P8A \\
\hline A3B- $08-45$ & $\mathrm{~S} 3$ & D2B-05-16 & P8B \\
\hline A3B-09-8 & S4A & D2B-06-8 & P9A \\
\hline A3B-09-25 & S4B & D2B-06-18 & $\mathrm{P} 9 \mathrm{~B}$ \\
\hline A3B-09-42 & $\mathrm{S} 4 \mathrm{C}$ & D2B-07-8 & $\mathrm{P} 2 \mathrm{~A}$ \\
\hline A3B-09-58 & S5 & D2B-07-15 & $\mathrm{P} 2 \mathrm{~B}$ \\
\hline D2B-01-8 & $\mathrm{P} 4 \mathrm{~A}$ & D2B-07-22 & $\mathrm{P} 2 \mathrm{C}$ \\
\hline D2B-01-20 & P4B & WLB-04-8 & P3A \\
\hline D2B-01-32 & $\mathrm{P} 4 \mathrm{C}$ & WLB-04-14 & P3B \\
\hline D2B-02-8 & $\mathrm{P} 5 \mathrm{~A}$ & WLB-04-28.75 & $\mathrm{P} 3 \mathrm{C}$ \\
\hline D2B-02-20 & P5B & WLB-04-45 & P3D \\
\hline D2B-02-37 & $\mathrm{P} 5 \mathrm{C}$ & WLB-05-8 & P1A \\
\hline D2B-02-52 & P5D & WB-05-19.5 & $\mathrm{P} 1 \mathrm{~B}$ \\
\hline D2B-02-73 & P5E & D2Y-01 & $\mathrm{P} 10$ \\
\hline D2B-02-76 & P5F & & \\
\hline D2B-03-8 & P6A & & \\
\hline D2B-03-25 & P6B & & \\
\hline
\end{tabular}




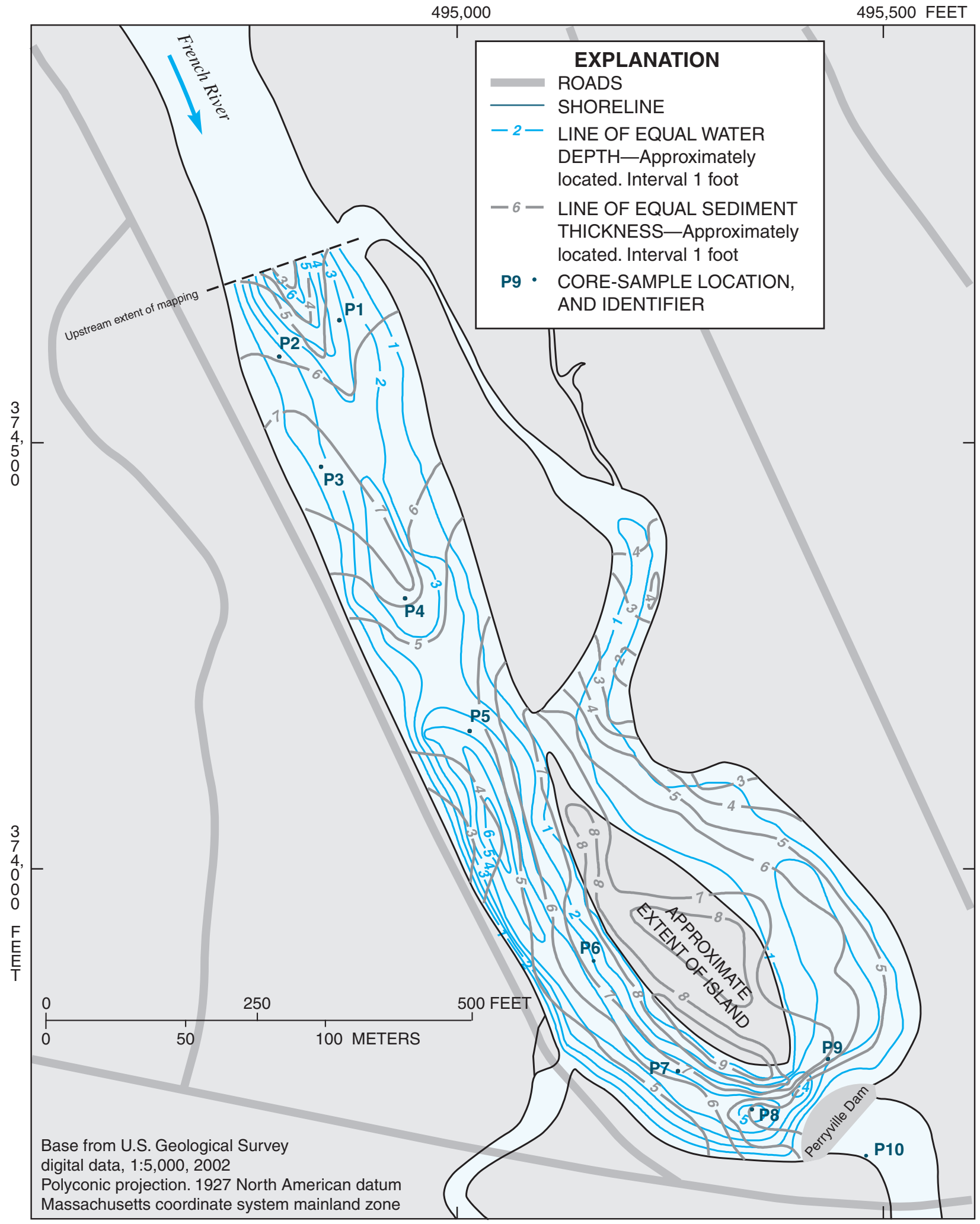

Figure 9. Bathymetric and bottom-sediment thickness map of Perryville Pond in Webster, Massachusetts. 
Much of this sediment has formed a large island in the center of the impoundment (fig. 9). Changing water levels caused the above-water extent of the island to vary considerably between visits; on one visit (July 2001), it was almost a peninsula, and on another visit (June 2002), it was mostly submerged. The sediments are deepest just upstream of the dam and extend in a fairly straight line away from it, with a maximum sediment thickness of $9.5 \mathrm{ft}$. Additional sediments may have accumulated in that area since the publication of the EIS. Moreover, changes in hydrology may have resulted in a net loss of sediment from some locations. The 1987 EIS indicates that the wetland plant, purple loosestrife, was uncommon in the Perryville Pond. During the July 2001 sampling trips, however, the exposed or shallow-water depositional zone extended well upstream from the front of the dam and was covered with this invasive species that reached heights of at least $8 \mathrm{ft}$; it towered over our heads. Water levels may have changed since the EIS was written; a decline in water level would have made the area more habitable by the loosestrife.

\section{Sediment Cores}

Cores were collected from nine locations within the impoundment (fig. 9) to provide the basis for assessing the physical and chemical characteristics of the sediments. A single sample was also collected from the right stream bank about $75 \mathrm{ft}$ downstream from the dam (P10) for comparison with the chemistry of the impounded sediments. The longest cores (both approximately $6 \mathrm{ft}$ long) came from sites P5 and P6 and were obtained with the Livingstone piston corer. At the bottoms of these cores, we found dense, coarse, fibrous material that may represent the remains of former bank or floodplain vegetation, indicating that coring had reached the bottom of the impoundment.

\section{Particle-Size Analysis}

Although the sediments were generally sandy, substantial fractions of some of the samples consisted of fine materials (table 6). Neither vertical nor horizontal patterns of particle-size distribution were apparent in the impoundment. Sample P5A (immediately upstream from the island) had the highest proportion (94.6 percent) of particles at least as large as fine sand $(>0.0625 \mathrm{~mm})$. Sample P8B contained the smallest proportion of particles larger than $0.0625 \mathrm{~mm}$ ( 23.7 percent) and the highest proportion ( 24.3 percent) of the smallest size fraction (clay; $<0.002 \mathrm{~mm}$ ); this sample was collected within a few yards of the dam. Two of the samples from site P3 also had relatively low percentages of the largest particles and high proportions of clays.

\section{Chemical Analyses}

Sediment samples were analyzed for organic compounds and trace metals. Results of these analyses indicated frequent detections of high concentrations.

\section{Organic Compounds}

The highest concentrations of organic compounds were detected at the upstream end of the impoundment and close to the dam (table 7). No patterns in vertical distribution were apparent; but since cores could not be obtained from equivalent depths everywhere, such patterns may have gone detected. Raw data (those extrapolated data not reported quantitatively here because the concentrations exceeded calibration levels) obtained with the ELISA method indicated that the high concentrations of PAHs and PCBs at Perryville approximated the median values of samples collected in bottom sediments in the lower Charles River, Massachusetts; the lower Charles flows through a highly urbanized basin characterized as having contaminant levels generally exceeding those detected in national studies of urban rivers (Breault and others, 2000). The PAH concentrations were also comparable to those reported at Perryville in the USEPA (1987) report. The concentrations of total chlordane in some samples were only slightly less than the concentrations determined in the samples of the Charles River sediments.

PAHs were detected in all but three of the samples, and concentrations ranged from $204 \mu \mathrm{g} / \mathrm{kg}$ to greater than $5,000 \mu \mathrm{g} / \mathrm{kg}$ (the upper limit of quantitation). Although their values exceeded the limit of quantitation, the two highest values (from the raw data) came from samples P8B and P1A. Samples P2B, $\mathrm{P} 2 \mathrm{C}$, and P3B had no detectable concentrations of PAHs. 
Table 6. Sediment particle-size distribution for samples collected from Perryville Pond, Webster, and from Silk Mill and Ballou impoundments, Becket, Massachusetts, July 2000

[Numbers in parentheses are the particle size. Not all samples were analyzed for particle-size distribution. Data represent the percent of the sample in a size class. Sediment sizes are in millimeters. DUP, duplicate quality-control sample; >, greater than; <, less than]

\begin{tabular}{|c|c|c|c|c|c|c|}
\hline \multirow[b]{2}{*}{ Sample ID } & \multicolumn{6}{|c|}{ Particle description } \\
\hline & $\begin{array}{c}\text { Fine sand } \\
\text { and larger } \\
(>0.0625)\end{array}$ & $\begin{array}{l}\text { Smaller than } \\
\text { fine sand } \\
(<0.0625)\end{array}$ & $\begin{array}{c}\text { Coarse silt } \\
(0.0625-0.016)\end{array}$ & $\begin{array}{c}\text { Fine silt } \\
(0.016-0.004)\end{array}$ & $\begin{array}{c}\text { Very fine silt } \\
(0.04-0.002)\end{array}$ & $\begin{array}{c}\text { Clay } \\
(<0.002)\end{array}$ \\
\hline \multicolumn{7}{|c|}{ Perryville Pond } \\
\hline P1A & 79.36 & 20.6 & 9.5 & 4.2 & 1.5 & 5.4 \\
\hline P1B & 82.55 & 17.4 & 8.1 & 3.2 & 1 & 5.1 \\
\hline $\mathrm{P} 2 \mathrm{~A}$ & 51.28 & 48.7 & 31.3 & 6.8 & 1.8 & 8.8 \\
\hline P2B & 52.5 & 47.5 & 33.9 & 4.2 & 2.9 & 6.5 \\
\hline $\mathrm{P} 2 \mathrm{C}$ & 44.04 & 56 & 37.4 & 7.7 & 1.8 & 9.1 \\
\hline P3A & 72.06 & 27.9 & 13.8 & 4.3 & 1.8 & 8 \\
\hline P3B & 38.01 & 62 & 45.4 & 3.5 & 2.2 & 10.9 \\
\hline $\mathrm{P} 3 \mathrm{C}$ & 24.61 & 75.4 & 50.1 & 10 & 2.8 & 12.5 \\
\hline P5A & 94.56 & 5.4 & 3.5 & 6 & .2 & 1.1 \\
\hline P5B & 80.94 & 19.1 & 13.8 & 1.8 & .4 & 3.1 \\
\hline P5C & 55.42 & 44.6 & 30 & 5.6 & 1.6 & 7.4 \\
\hline P5C-DUP & 55.42 & 44.6 & 29.9 & 5.9 & 2.1 & 6.7 \\
\hline P6A & 59.11 & 40.9 & 23 & 6.8 & 1.8 & 9.3 \\
\hline P6B & 71.71 & 28.3 & 19.8 & 2.2 & 1.2 & 5.1 \\
\hline P6C & 58.78 & 41.2 & 29.1 & 2.7 & 1.6 & 7.8 \\
\hline P7A & 89.07 & 10.9 & 6.2 & 1.9 & .3 & 2.5 \\
\hline P7B & 74.97 & 25 & 11.7 & 4.1 & 1.9 & 7.3 \\
\hline P7C & 86.01 & 14 & 9.9 & 1.5 & .6 & 2 \\
\hline P8A & 62.33 & 37.7 & 16.9 & 6.8 & 2.7 & 11.3 \\
\hline P8B & 23.73 & 76.3 & 29.8 & 16.1 & 6.1 & 24.3 \\
\hline P10 & 86.78 & 13.2 & 8.4 & 1.2 & .6 & 3 \\
\hline \multicolumn{7}{|c|}{ Silk Mill } \\
\hline S4A & 92.15 & 7.8 & 4.8 & 1.3 & 0.5 & 1.2 \\
\hline S4B & 89.84 & 10.2 & 5.8 & 1.5 & .7 & 2.2 \\
\hline $\mathrm{S} 4 \mathrm{C}$ & 95.44 & 4.6 & 2.6 & .8 & .2 & 1 \\
\hline S5 & 96.87 & 3.1 & 1.5 & .6 & .2 & .8 \\
\hline \multicolumn{7}{|c|}{ Ballou } \\
\hline B1A & 82.24 & 17.8 & 11 & 2.7 & 0.8 & 3.3 \\
\hline B1B & 98.8 & 1.1 & .7 & .1 & .1 & 0.2 \\
\hline
\end{tabular}


Table 7. Results of ELISA analyses of organic sediment constituents in samples collected from Perryville Pond, Webster, and from Silk Mill and Ballou impoundments, Becket, Massachusetts

[PAH, polycyclic aromatic hydrocarbon; PCB, polychlorinated biphenyl; TPH, total petroleum hydrocarbon; $\mu \mathrm{g} / \mathrm{kg}$, micrograms per kilogram; $\mathrm{mg} / \mathrm{kg}$, milligrams per kilogram; >, actual value is greater than value shown; --, not detected]

\begin{tabular}{|c|c|c|c|c|c|c|c|c|c|}
\hline $\begin{array}{l}\text { Sample } \\
\text { ID }\end{array}$ & $\begin{array}{c}\text { PAH } \\
(\mu \mathrm{g} / \mathrm{kg})\end{array}$ & $\begin{array}{c}\text { TPH } \\
(\mathrm{mg} / \mathrm{kg})\end{array}$ & $\begin{array}{c}\text { PCB } \\
(\mu \mathrm{g} / \mathrm{kg})\end{array}$ & $\begin{array}{c}\text { Chlordane } \\
\text { ( } \mu \mathrm{g} / \mathrm{kg})\end{array}$ & $\begin{array}{l}\text { Sample } \\
\text { ID }\end{array}$ & $\begin{array}{c}\text { PAH } \\
(\mu \mathrm{g} / \mathrm{kg})\end{array}$ & $\begin{array}{c}\mathrm{TPH} \\
(\mathrm{mg} / \mathrm{kg})\end{array}$ & $\begin{array}{c}\text { PCB } \\
(\mu \mathrm{g} / \mathrm{kg})\end{array}$ & $\begin{array}{c}\text { Chlordane } \\
(\mu \mathrm{g} / \mathrm{kg})\end{array}$ \\
\hline \multicolumn{5}{|c|}{ Perryville Pond } & \multicolumn{5}{|c|}{ Silk Mill } \\
\hline $\mathrm{P} 1 \mathrm{~A}$ & $>5,000$ & 21.1 & 660 & $>600$ & S1A & 2,670 & -- & -- & -- \\
\hline P1B & $>5,000$ & 38.1 & 760 & $100-600$ & S1B & 4,050 & -- & -- & -- \\
\hline $\mathrm{P} 2 \mathrm{~A}$ & 1,120 & -- & -- & $20-100$ & S1C & $>5,000$ & -- & -- & -- \\
\hline $\mathrm{P} 2 \mathrm{~B}$ & -- & -- & -- & -- & S2A & 2,620 & -- & -- & -- \\
\hline $\mathrm{P} 2 \mathrm{C}$ & -- & -- & -- & -- & S2B & 2,610 & -- & -- & -- \\
\hline P3A & $>5,000$ & 17.2 & 640 & $100-600$ & $\mathrm{~S} 2 \mathrm{C}$ & 2,260 & -- & -- & -- \\
\hline P3B & -- & -- & -- & -- & S3 & 3,070 & -- & -- & -- \\
\hline $\mathrm{P} 3 \mathrm{C}$ & 204 & -- & -- & -- & S4A & 4,340 & -- & -- & -- \\
\hline $\mathrm{P} 4 \mathrm{~A}$ & $>5,000$ & 2.30 & -- & $100-600$ & S4B & 2,200 & -- & -- & -- \\
\hline P4B & $>5,000$ & 9.60 & -- & $100-600$ & S4C & $>5,000$ & -- & -- & -- \\
\hline $\mathrm{P} 4 \mathrm{C}$ & $>5,000$ & 14.8 & 540 & $>600$ & S5 & 3,030 & -- & -- & -- \\
\hline P5A & $>5,000$ & 1.10 & -- & $100-600$ & \multicolumn{5}{|c|}{ Ballou } \\
\hline P5B & 4,470 & 1.10 & -- & -- & B1A & 2,660 & -- & -- & 20-100 \\
\hline $\mathrm{P} 5 \mathrm{C}$ & 1,670 & -- & -- & -- & $\mathrm{B} 1 \mathrm{~B}$ & 2,990 & -- & -- & -- \\
\hline P5D & 485 & -- & -- & -- & $\mathrm{B} 1 \mathrm{C}$ & $>5,000$ & -- & -- & -- \\
\hline P6A & $>5,000$ & -- & -- & $100-600$ & & & & & \\
\hline P6B & 4,160 & 1.00 & -- & $20-100$ & & & & & \\
\hline P6C & $>5,000$ & 1.50 & -- & $20-100$ & & & & & \\
\hline P7A & $>5,000$ & 1.10 & -- & $100-600$ & & & & & \\
\hline P7B & $>5,000$ & 4.00 & -- & $20-100$ & & & & & \\
\hline P7C & $>5,000$ & -- & -- & -- & & & & & \\
\hline P8A & $>5,000$ & 10.0 & -- & $100-600$ & & & & & \\
\hline P8B & $>5,000$ & 27.10 & 640 & $20-100$ & & & & & \\
\hline P9A & $>5,000$ & 1.50 & -- & $20-100$ & & & & & \\
\hline P9B & $>5,000$ & 1.20 & -- & $100-600$ & & & & & \\
\hline P10 & $>5,000$ & -- & -- & $20-100$ & & & & & \\
\hline
\end{tabular}


TPHs were detected in 60 percent of the samples at concentrations ranging from 1 to greater than 30 $\mathrm{mg} / \mathrm{kg}$. The highest concentrations were detected in samples P1A, P1B, P3A, P4C, and P8B. All samples from $\mathrm{P} 1$ and $\mathrm{P} 8$ had a detectable level of TPHs. The TPH concentrations exceeded by one to two orders of magnitude those reported for the individual BTEX compounds in the USEPA (1987) report (table 8).

Only five samples, collected at four sites, contained detectable concentrations of PCBs. These concentrations were detected in the same samples as the five highest TPH concentrations listed above. The PCB concentrations ranged from 540 to $760 \mu \mathrm{g} / \mathrm{kg}$.

Chlordane was detected in 70 percent of the samples collected from Perryville Pond. Two samples (P1A, P4C) had concentrations exceeding $600 \mu \mathrm{g} / \mathrm{kg}$.

\section{Trace Metals}

The following discussions of the results of analyses for trace elements focus on the concentrations of six metals: arsenic (As), cadmium (Cd), copper $(\mathrm{Cu})$, lead $(\mathrm{Pb})$, nickel $(\mathrm{Ni})$, and zinc $(\mathrm{Zn})$ (table 9) from among the 30 elements analyzed by XRAL Laboratories, Inc. (appendix, at back of report) ${ }^{2}$. Concentrations of metals differed widely, but the highest concentrations were generally detected in samples collected at sites nearest to the dam (sites P8 and P9). Sample P8B had the highest concentrations of $\mathrm{Cu}$ and $\mathrm{Pb}$, and among the highest concentrations of $\mathrm{As}, \mathrm{Cd}, \mathrm{Ni}$, and $\mathrm{Zn}$; this sample also had the highest proportion of clay material as indicated in the particlesize analysis. The highest concentration of As was found in the surface sample collected from the riverbank just downstream from the dam (site P10). High concentrations of As were also found in samples from sites in the impoundment closest to the dam; most of these concentrations were more than double that of the next highest As sample concentration. The three samples with the highest concentrations of $\mathrm{Cd}$,

\footnotetext{
${ }^{2}$ This study included chromium as one of the target analytes. However, results suggested that sample processing may have introduced contamination and, thus, all references to chromium detections and concentrations have been deleted from this report.
}

Table 8. Selected constituent concentrations in sediment samples from vegetated and open-water zones of Perryville Pond, Massachusetts, 1984

[U.S. Environmental Protection Agency, 1987. PAH, polycyclic aromatic hydrocarbon; TPH, total petroleum hydrocarbon; $\mu \mathrm{g} / \mathrm{kg}$, micrograms per kilogram; mg/kg, milligrams per kilogram; --, not detected]

\begin{tabular}{|c|c|c|}
\hline Constituent & Vegetated zone & Open-water zone \\
\hline \multicolumn{3}{|c|}{ Metals (mg/kg) } \\
\hline Arsenic & 25 & 23 \\
\hline Cadmium & 1.7 & 3.6 \\
\hline Chromium & 220 & 630 \\
\hline Copper & 83 & 350 \\
\hline Lead & 81 & 220 \\
\hline Nickel & 9 & 11 \\
\hline Zinc & 180 & 440 \\
\hline \multicolumn{3}{|c|}{$\mathbf{P A H}(\mu \mathbf{g} / \mathbf{k g})$} \\
\hline Acenaphthene & 2,300 & trace \\
\hline Fluoranthene & 4,700 & 15,000 \\
\hline Naphthalene & 1,000 & trace \\
\hline $\operatorname{Benzo}(a)$ anthracene & 2,300 & 12,000 \\
\hline $\operatorname{Benzo}(a)$ pyrene & 1,200 & 9,000 \\
\hline Benzofluoranthene & 1,400 & 10,000 \\
\hline Chrysene & 2,000 & 10,000 \\
\hline Anthracene & 3,400 & 11,000 \\
\hline $\operatorname{Benzo}(g, h, i)$ perylene & 530 & trace \\
\hline Phenanthrene & 8,000 & 22,000 \\
\hline Pyrene & 8,100 & 23,000 \\
\hline \multicolumn{3}{|c|}{ TPH $(\mu \mathrm{g} / \mathbf{k g})$} \\
\hline Acetone & 160 & -- \\
\hline Toluene & 10 & 130 \\
\hline Chlorobenzene & -- & 49 \\
\hline Ethylene & -- & 12 \\
\hline Total xylene & 10 & 15 \\
\hline
\end{tabular}

$\mathrm{Cu}, \mathrm{Pb}$, and $\mathrm{Zn}$ came from the same two sites in the impoundment nearest to the dam; again, like the highconcentration As samples, the concentrations of $\mathrm{Cd}, \mathrm{Cu}$, $\mathrm{Pb}$, and $\mathrm{Zn}$ were commonly greater than twice the next highest sample concentration. Site P1, at the upstream end of the impoundment, also exhibited high concentrations of these metals. The concentration ranges for these metals appeared comparable to the results from the lower Charles River study (Breault and others, 2000). The metal-concentration ranges closely corresponded with values included in the USEPA (1987) report (table 8). 
Table 9. Concentrations of selected metals analyzed by XRAL Laboratories

[All concentrations are milligrams per kilogram. DUP, duplicate control-quality sample; <, actual value is less than value shown]

\begin{tabular}{|c|c|c|c|c|c|c|}
\hline Sample ID & Arsenic & Cadmium & Copper & Nickel & Lead & Zinc \\
\hline P1A & 12 & 2 & 336 & 22 & 250 & 385 \\
\hline P1B & 6 & 1 & 116 & 18 & 219 & 288 \\
\hline $\mathrm{P} 2 \mathrm{~A}$ & 4 & $<1$ & 9.6 & 16 & 13 & 27.6 \\
\hline P2B & 8 & $<1$ & 6.1 & 19 & 11 & 25.8 \\
\hline $\mathrm{P} 2 \mathrm{C}$ & 8 & $<1$ & 4.4 & 19 & 5 & 27.1 \\
\hline P3A & 14 & 2 & 258 & 22 & 213 & 499 \\
\hline P3B & 4 & $<1$ & 5.3 & 16 & 5 & 21.5 \\
\hline P3C & 10 & $<1$ & 5.1 & 21 & 5 & 31.6 \\
\hline $\mathrm{P} 4 \mathrm{~A}$ & 3 & $<1$ & 25.6 & 13 & 64 & 74.3 \\
\hline P4B & 6 & $<1$ & 29.4 & 14 & 68 & 59.3 \\
\hline $\mathrm{P} 4 \mathrm{C}$ & 8 & 2 & 239 & 21 & 179 & 263 \\
\hline P5A & 4 & $<1$ & 27.7 & 16 & 67 & 51.5 \\
\hline P5B & $<3$ & $<1$ & 9 & 11 & 9 & 12.2 \\
\hline P5C & 8 & $<1$ & 3 & 11 & 5 & 13.7 \\
\hline P6A & 7 & 2 & 247 & 24 & 211 & 177 \\
\hline P6B & $<3$ & $<1$ & 12.2 & 11 & 9 & 28.1 \\
\hline P6C & $<3$ & $<1$ & 16.1 & 14 & 15 & 29.8 \\
\hline P7A & 5 & $<1$ & 40.2 & 17 & 58 & 69 \\
\hline P7B & 9 & 2 & 161 & 14 & 187 & 218 \\
\hline P7C & $<3$ & $<1$ & 10.5 & 10 & 20 & 20.7 \\
\hline P8A & 35 & 5 & 346 & 26 & 459 & 897 \\
\hline P8B & 54 & 5 & 734 & 22 & 528 & 842 \\
\hline P9A & 28 & 10 & 533 & 20 & 515 & 824 \\
\hline P9B & 10 & 2 & 194 & 16 & 136 & 134 \\
\hline P10 & 59 & $<1$ & 44.9 & 15 & 72 & 75 \\
\hline S1A & $<3$ & $<1$ & 9.8 & 18 & 17 & 65.9 \\
\hline S1B & $<3$ & $<1$ & 12.4 & 14 & 15 & 61.6 \\
\hline S1C & $<3$ & $<1$ & 6.6 & 11 & 12 & 48.4 \\
\hline S2A & $<3$ & $<1$ & 11.7 & 15 & 26 & 78.3 \\
\hline S2B & $<3$ & $<1$ & 12.2 & 17 & 37 & 89.6 \\
\hline $\mathrm{S} 2 \mathrm{C}$ & $<3$ & $<1$ & 16.4 & 15 & 43 & 106 \\
\hline S3 & $<3$ & $<1$ & 10.1 & 13 & 29 & 72 \\
\hline S4A & $<3$ & $<1$ & 9.3 & 13 & 11 & 56.7 \\
\hline S4B & $<3$ & $<1$ & 8.4 & 13 & 15 & 66 \\
\hline $\mathrm{S} 4 \mathrm{C}$ & $<3$ & $<1$ & 7.7 & 10 & 15 & 51.8 \\
\hline S5 & $<3$ & $<1$ & 6.7 & 12 & 14 & 43 \\
\hline $\mathrm{B} 1 \mathrm{~A}$ & $<3$ & $<1$ & 11.5 & 14 & 20 & 87 \\
\hline B1B & $<3$ & $<1$ & 7.3 & 11 & 11 & 40.1 \\
\hline $\mathrm{B} 1 \mathrm{C}$ & $<3$ & $<1$ & 10.1 & 12 & 12 & 46.6 \\
\hline DUP-P8A & 32 & 4 & 316 & 25 & 420 & 823 \\
\hline DUP-P4C & 6 & 1 & 226 & 21 & 163 & 247 \\
\hline DUP-P10 & 59 & $<1$ & 44.2 & 16 & 67 & 74.6 \\
\hline DUP-B1A & $<3$ & $<1$ & 11.5 & 14 & 20 & 88.7 \\
\hline
\end{tabular}




\section{ANALYTICAL RESULTS FOR SILK MILL AND BALLOU}

As with the Perryville Pond interpretations, this study bases its determination of the Becket impoundments' bathymetry, sediment distribution, and sediment volume on interpretation of the data obtained by manually probing the sediments and measuring the water and sediment depths. (figs. 10, 11).

\section{Bathymetric Mapping}

The Silk Mill and Ballou Dams serve as passive, run-of-the-river dams that were built on rock outcrops where waterfalls likely existed. The impoundments behind these dams are relatively shallow (maximum depths of about 5 and $6 \mathrm{ft}$ for Silk Mill and Ballou, respectively, at the times of our visits) and have little storage capacity due to sediment deposition.

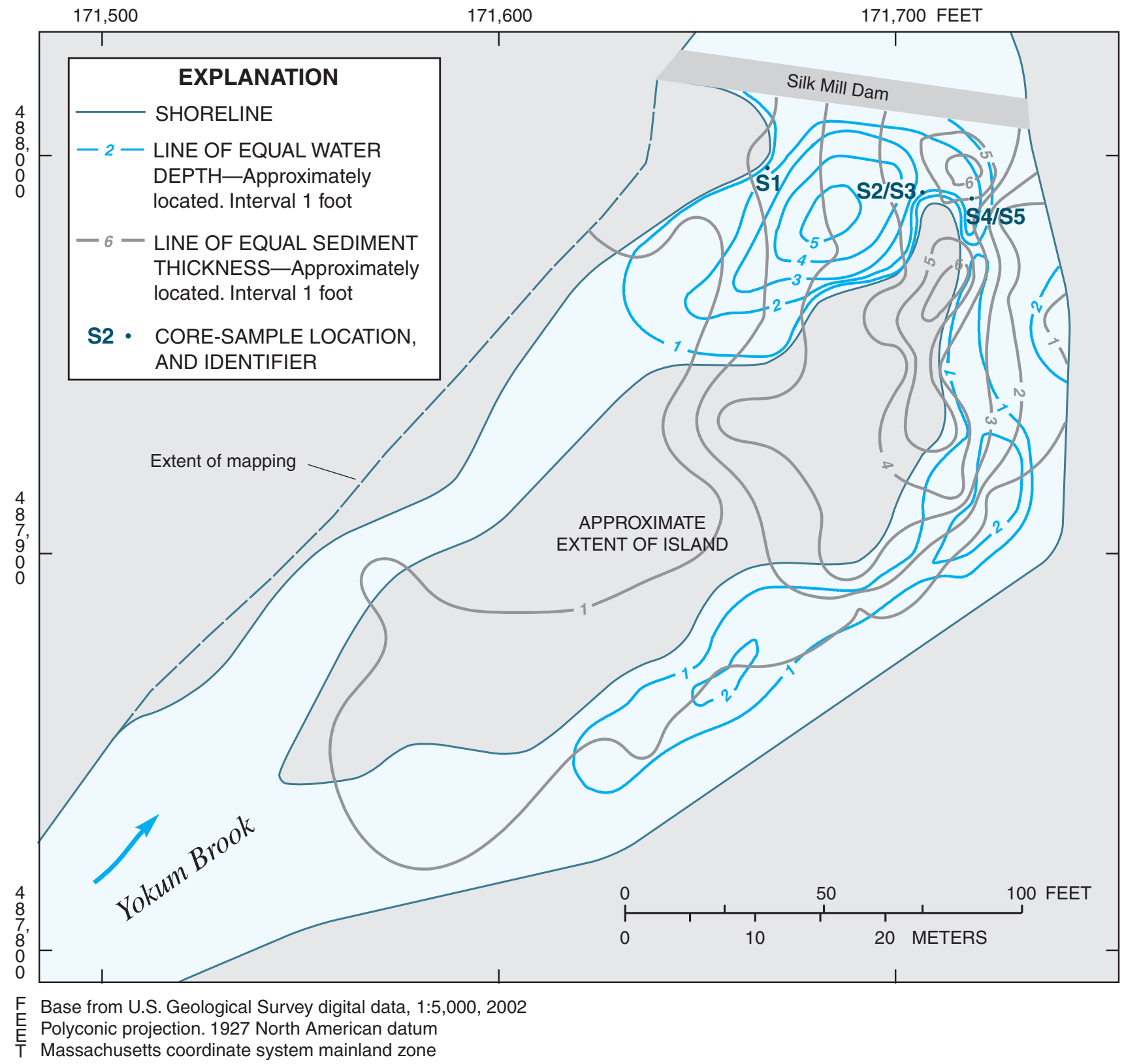

Figure 10. Bathymetric and bottom-sediment thickness map of Silk Mill impoundment, Becket, Massachusetts. 


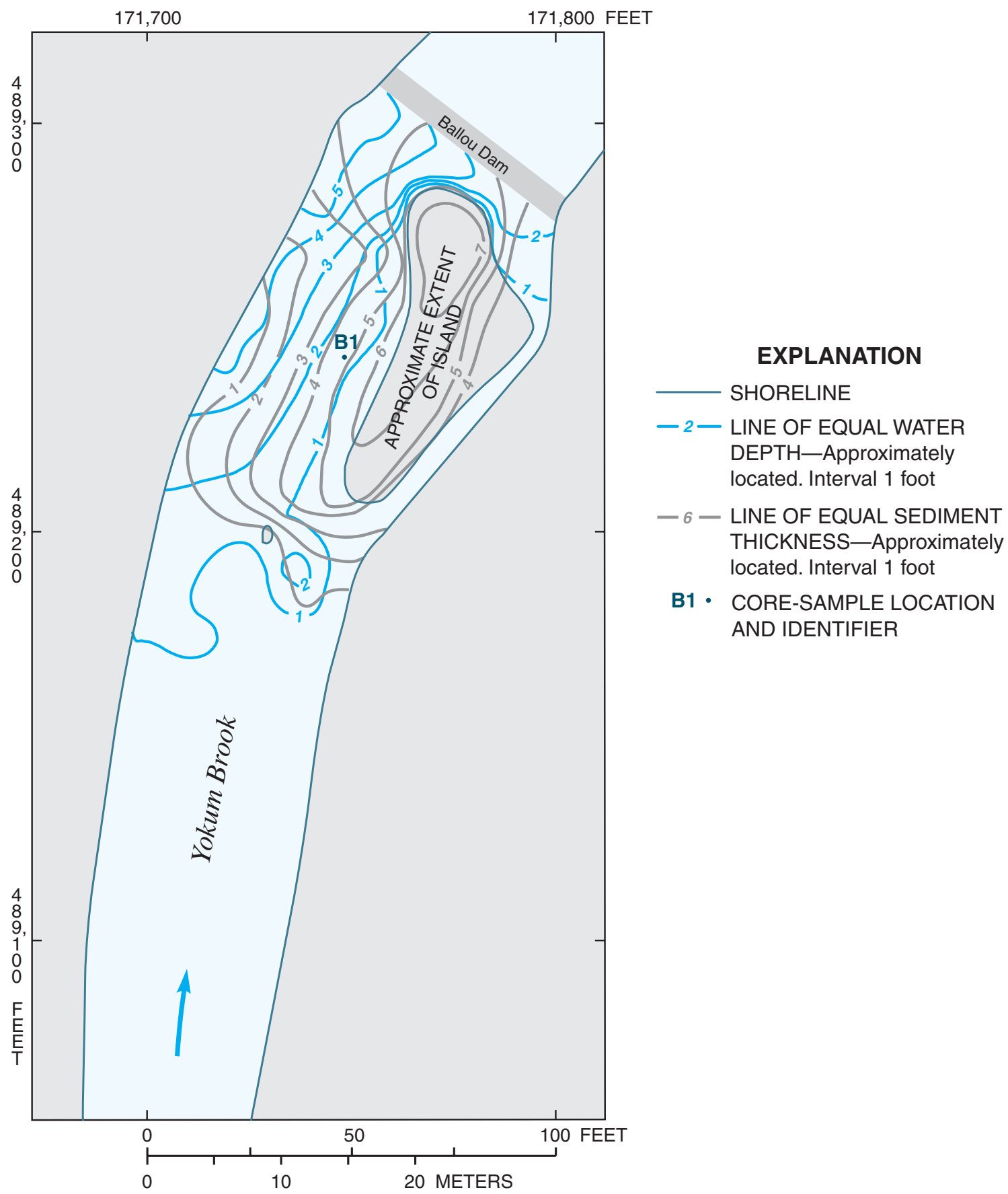

Base from U.S. Geological Survey digital data, 1:5,000, 2002

Polyconic projection. 1927 North American datum

Massachusetts coordinate system mainland zone

Figure 11. Bathymetric and bottom-sediment thickness map of Ballou impoundment, Becket, Massachusetts. 
During the 1920s, the storage capacity of the Silk Mill impoundment was also reduced by a flood that deposited large boulders.

Most of Yokum Brook's flow in the Silk Mill impoundment passes along the west side. Under relatively high-flow conditions, the streamflow may split and surround the depositional island that has formed. Under low-flow conditions, the channel along the eastern bank may receive some ground-water discharge, but the channel basically becomes a backwater. At several points in the impoundment, there are gaps in the bottom sediment through which water and sediment can flow, eventually passing through an opening in the face of the dam. The most notable one is at the deepest point, between coring sites $\mathrm{S} 1$ and $\mathrm{S} 2 / 3$ (fig. 10).

In and upstream from the Ballou Dam impoundment, Yokum Brook also splits to surround the main depositional island and other small outcrops. Walls along the east and west banks constrain the impoundment; and although the Ballou impoundment is smaller than that at the Silk Mill Dam, its pool area is relatively more extensive.

\section{Sediment Volume and Coring}

Approximately 1,600 cubic yards of sediment remain trapped behind the Silk Mill Dam and about 800 cubic yards are trapped behind the Ballou Dam. As in the case of Perryville Pond, most fine-grained sediment in these impoundments occurs as deposits forming large islands covered by a variety of plants, from shrubs and grasses to mature trees.

Cores were collected from three locations in the Silk Mill Pond (fig. 10) and from a single site in the Ballou pool (fig. 11). One of the Silk Mill locations was along the left bank, while the others were along the downstream end of the extensive depositional area that constituted an island and largely filled the impoundment. Pairs of cores, S2/S3 and S4/S5, were collected such that S3 and S5 represent sections immediately adjacent to and deeper than cores $\mathrm{S} 2$ and S4, respectively. Thus, in the Silk Mill impoundment, cores represent almost $5 \mathrm{ft}$ of sediment deposition. The single core obtained in the Ballou impoundment was about $4 \mathrm{ft}$ long (fig. 8).

\section{Particle-Size Distribution}

In contrast to the sediments at Perryville Pond, the sediments in samples collected from the Becket impoundments are uniformly characterized by a high percentage of particles at least as large as fine sand (0.0625 mm; table 6). Sample B1A contained the highest percentage ( 3.3 percent) of the smallest size class (clay).

\section{Chemical Analyses}

The ELISA analyses indicated no detectable concentrations of PCBs or TPHs (table 7) in either of the Becket impoundments. PAHs were detected in all samples at concentrations ranging from about $2,000 \mathrm{mg} / \mathrm{kg}$ to greater than $5,000 \mathrm{mg} / \mathrm{kg}$. The raw (extrapolated beyond the range of calibration concentrations) data indicated that the maximum PAH concentrations in the Becket impoundments fell well below those in Perryville. Chlordane was detected in a single sample (B1A) from the Ballou sediments. Its concentration was in the low range and was quantifiable as $34.9 \mu \mathrm{g} / \mathrm{kg}$ (listed as $20-100 \mu \mathrm{g} / \mathrm{kg}$ in table 7).

Potentially toxic metals were not detected in elevated concentrations (table 9). The concentrations were generally lower than the high concentrations detected in Perryville Pond.

\section{APPLICATION OF GUIDELINES FOR ASSESSING SEDIMENT CHEMISTRY}

Data were analyzed to indicate whether or not enough samples were taken to adequately characterize sediment quality. This study also examined the relation of contaminant concentrations to particle-size fractions in order to provide useful information for deciding among options for sediment management (off-site disposal, on-site stabilization, or downstream redistribution). To categorize the potential toxicity to invertebrates of the sediment samples analyzed, mean MPP values derived from our data are compared with those assembled for the USEPA (2000b) consensus toxicity guidelines. 


\section{Number of Samples Analyzed}

Accurate characterization of sediment chemistry, in terms of mean concentrations calculated by using equation 1 , for example, would call for substantially more samples from the Perryville impoundment than from the Becket impoundments (table 10). The due-diligence review revealed that the history of contamination in the Perryville drainage basin would suggest the likelihood of greater variability of contaminant concentrations associated with human activities (for example, copper, lead, mercury, nickel, and zinc) than in Yokum Brook, and hence, the need for additional samples to describe the mean. Many of the analytical concentrations falling at or below the levels of detection in the Becket impoundments showed little variability, and thus, would not require further sampling to adequately characterize the mean. In other words, the data collected from the Becket impoundments are representative, in terms of the mean, for most physical properties and chemical concentrations. It is important to note that this interpretation assumes that the "true" variability in physical properties and chemical concentrations was sampled in the impounded sediments.

On the other hand, regulations may prescribe a different method for determining a minimum sample number. For example, Massachusetts Department of Environmental Protection (MADEP) draft guidelines require projects at sites with greater than 10,000 cubic yards of sediment to collect a minimum of two samples; for sites with less than 10,000 cubic yards, one sample per 1,000 cubic yards is required (S. Lipman, Massachusetts Department of Environmental Protection, written commun., 2001). These guidelines would have required only two samples each from Perryville Pond and Silk Mill Dam sediments and one from Ballou Dam. The data in table 10 suggest that these numbers would generally undersample Perryville and oversample Becket. This finding indicates the value of a scientifically based approach to sediment-sampling design.
Table 10. Number of samples needed to define the mean concentrations of analytes within 25 percent and with 90 percent confidence for Perryville Pond and the two Becket impoundments (Silk Mill and Ballou combined), Massachusetts

[PAH, polycyclic aromatic hydrocarbon; PCB, polychlorinated biphenyl; TPH, total petroleum hydrocarbon]

\begin{tabular}{|c|c|c|}
\hline Analyte & Perryville & Becket \\
\hline Aluminum & 9 & 4 \\
\hline Arsenic & 70 & 1 \\
\hline Antimony & 11 & 1 \\
\hline Barium & 31 & 5 \\
\hline Beryllium & 7 & 1 \\
\hline Bismuth & 1 & 1 \\
\hline Cadmium & 53 & 1 \\
\hline Calcium & 9 & 3 \\
\hline Cobalt & 10 & 3 \\
\hline Copper & 91 & 5 \\
\hline Iron & 7 & 2 \\
\hline Lanthanum & 8 & 2 \\
\hline Lead & 70 & 14 \\
\hline Lithium & 6 & 3 \\
\hline Magnesium & 6 & 2 \\
\hline Manganese & 8 & 6 \\
\hline Molybdenum & 7 & 5 \\
\hline Nickel & 4 & 2 \\
\hline Phosphorus & 21 & 2 \\
\hline Potassium & 12 & 2 \\
\hline Scandium & 11 & 2 \\
\hline Silver & 88 & 2 \\
\hline Sodium & 4 & 6 \\
\hline Strontium & 13 & 4 \\
\hline Tin & 47 & 1 \\
\hline Titanium & 12 & 3 \\
\hline Tungsten & 1 & 1 \\
\hline Vanadium & 8 & 3 \\
\hline Yttrium & 12 & 3 \\
\hline Zinc & 87 & 6 \\
\hline Zirconium & 11 & 4 \\
\hline Chlordane & 61 & 1 \\
\hline PAH & 14 & 6 \\
\hline PCB & 2 & 1 \\
\hline TPH & 116 & 1 \\
\hline
\end{tabular}




\section{Contaminant Concentrations and Exceedance Guidelines}

Examination of the relation of contaminant concentrations to particle-size fractions showed that the highest concentrations of contaminants were found in association with the highest concentrations of clay particles. It is also worthwhile to compare the concentrations of contaminants with guidelines that are based on management criteria and potential biological effects. Breault and others (2000) presented concentration guidelines for potentially adverse effects of contaminated sediments on benthic organisms and on humans through epidermal contact (Ecosystem Conservation Directorate Evaluation and Interpretation Branch, 1995). To compare this study's results with those guidelines, the work of Breault and others (2000) has been summarized and synthesized with the USEPA consensus sediment-toxicity guidelines (U.S. Environmental Protection Agency, 2000b). The guidelines list Threshold Effect Levels (TEL), the concentrations below which adverse effects on benthic organisms are rarely observed, and Probable Effect Levels (PEL), the concentrations above which adverse effects on benthic organisms are commonly observed, for some specific polycyclic aromatic hydrocarbons in freshwater sediments (table 11). The PEL contrasts with the PEC, the concentration above which one expects to observe adverse effects on benthic organisms.

At neither Perryville nor Becket did any of the PAH (within the quantifiable range) or TPH concentrations exceed the criteria for Probable Effect Concentration (PEC) $(22,800 \mu \mathrm{g} / \mathrm{kg})$ or for human contact $(800,000 \mu \mathrm{g} / \mathrm{kg})$; but additional testing,
Table 11. Sediment-quality guidelines for freshwater benthic organisms and human-contact data

[Breault and others, 2000. PAH, polycyclic aromatic hydrocarbon; PCB, polychlorinated biphenyl; TPH, total petroleum hydrocarbon; PEL, Probable Effect Level, concentration above which adverse effects are commonly observed; PEC, Probable Effect Concentration, concentration above which adverse effects are expected (USEPA, 2000b); TEL, Threshold Effect Level, concentration below which adverse effects are rarely observed. $\mu \mathrm{g} / \mathrm{kg}$, micrograms per kilogram; mg/kg, milligrams per kilogram; --, no value available]

\begin{tabular}{lcccr}
\hline Constituent or class & TEL & PEL & PEC & $\begin{array}{r}\text { Human } \\
\text { contact }\end{array}$ \\
\hline \multicolumn{5}{c}{ Organics $(\mu \mathbf{g} / \mathbf{k g})$} \\
TPH & -- & -- & -- & 800,000 \\
Total PAH & -- & -- & 22,800 & -- \\
Total PCB & 34.1 & 277 & 676 & 2,000 \\
Total chlordane & 4.5 & 8.9 & 17.6 & 1,000 \\
\multicolumn{5}{c}{ Metals $(\mathbf{m g} / \mathbf{k g})$} \\
Arsenic & 5.9 & 17 & 33.0 & \\
Cadmium & 0.6 & 3.53 & 4.98 & 30 \\
Chromium & 37.3 & 90 & 111 & 1,000 \\
Copper & 35.7 & 197 & 149 & -- \\
Nickel & 18 & 35.9 & 48.6 & 300 \\
Lead & 35 & 91.3 & 128 & 300 \\
Zinc & 123 & 315 & 459 & 2,500 \\
\hline
\end{tabular}

if necessary, can confirm the true magnitudes of the concentrations. None of the detected PCB concentrations exceeded the human-contact threshold, but the values did exceed both the TEL and PEL for freshwater benthic organisms. These PCB concentrations are comparable to those detected in the lower Charles River Basin (Breault and others, 2000), but are considerably less than those found in the East Branch of the Housatonic River Basin in Massachusetts 
(Harris, 1997) where a major point-source discharge caused the contamination. Because the Minimum Detection Level (MDL) by ELISA for total chlordane, $20 \mu \mathrm{g} / \mathrm{kg}$, is greater than either the TEL or PEL, all detections exceeded those levels; that is, many samples from Perryville and one from Ballou had concentrations exceeding these levels. Only two chlordane concentrations were greater than $600 \mu \mathrm{g} / \mathrm{kg}$; therefore, these concentrations could exceed the human-contact criterion.

Many of the sediment samples collected from Perryville Pond contained metal concentrations that exceeded criteria for benthic organisms and human contact. In general, the samples with the highest metal concentrations came from sites P1, P8, and P9; additional samples with high metals concentrations came from sites P3, P4, P6, and P7. Arsenic concentrations, where detected, generally exceeded the TEL but not the PEL; only at P8, P9, and P10 did the concentrations exceed the PEL and the human-contact criterion of $30 \mathrm{mg} / \mathrm{kg}$. The MDL for Cd $(1 \mathrm{mg} / \mathrm{kg})$ is greater than the TEL $(0.6 \mathrm{mg} / \mathrm{kg})$, so it is conceivable that all samples had concentrations of at least that value; only samples from sites $\mathrm{P} 8$ and $\mathrm{P} 9$ exceeded the PEL; none exceeded the human-contact criterion of $30 \mathrm{mg} / \mathrm{kg}$. About half (12) of the $\mathrm{Cu}$ concentrations exceeded the TEL, but only seven exceeded the PEL; currently, there is no human-contact criterion. Sixty percent of the samples had $\mathrm{Pb}$ concentrations exceeding the TEL, and most of those also exceeded the PEL; three samples collected at sites P8 and P9 exceeded the human-contact criterion. For Ni, 11 samples exceeded the TEL but none exceeded the PEL. For Zn, 10 samples exceeded the TEL and 5 the PEL.

At Becket, there were no samples in which metal concentrations exceeded human-contact guidelines. Only two samples contained $\mathrm{Pb}$ concentrations slightly in excess of the TEL. No samples for the other metals considered here exceeded the toxicity standards we use.

\section{Contaminants and Their Potential Toxicity}

Examination of sample results for potential toxicity showed that samples collected at Perryville sites $1,3,4,8$, and 9 stood out in terms of potential toxicity; samples P8B and P9A had the highest MPP values, 1.7 and 0.90 , respectively. Individual samples from sites 1, 3, and 4 in Perryville Pond also exceeded the 0.5 value. This analysis reinforces the biological implications of the high chemical-contaminant concentration levels. Samples from the two Becket impoundments exhibited mean MPP values in the lowest potential toxicity category found in this study $(0.1<$ Mean MPP $<0.5)$.

In terms of toxicity, only the P8B sediments seem likely to prove lethal to 50 percent or more of the test organisms (table 12) on the basis of the analysis of this particular dataset. Other combinations of analytes, including chromium, would be expected to yield different results. The HA28 (Hyalella azteca 28-day toxicity test) seemed more sensitive at high values of mean MPP than the shorter duration tests. However, for mean MPP values less than 0.5, toxicity, as indicated by the HA28 test, was relatively low. These interpretations of toxicity, based on a comparison with all the data compiled by the USEPA (2000b), do not take into account regional variability in the results of the computations. None of the data in the compilation were derived from studies in New England, let alone in the specific basins in Massachusetts. 
Table 12. Incidence of toxicity based on Probable Effect Concentration (PEC) quotients in samples from Perryville Pond, Webster, and from Silk Mill and Ballou impoundments, Becket, Massachusetts

[Percent species toxicity data from U.S. Environmental Protection Agency, 2000b. Mean MPP, average of PEC quotients; $\mathrm{X}$, indicates the range within which the Mean MPP value lies; CS10, Chironomus spp. 10-day toxicity test; HA10, Hyalella azteca 10-day toxicity test; HA28, Hyalella azteca 28-day toxicity test; NC, not calculated; <, less than; >, greater than]

\begin{tabular}{|c|c|c|c|c|c|c|c|}
\hline \multirow{6}{*}{$\begin{array}{c}\text { Sample } \\
\text { ID }\end{array}$} & \multirow{6}{*}{$\begin{array}{l}\text { Mean } \\
\text { MPP }\end{array}$} & \multicolumn{6}{|c|}{ Percent toxicity by mean MPP range } \\
\hline & & \multirow{2}{*}{\multicolumn{2}{|c|}{$<0.1$}} & & & & \\
\hline & & & & $0.1<0.5$ & & & \multirow{4}{*}{$\begin{array}{c}>1.0 \\
66 \\
100 \\
60\end{array}$} \\
\hline & & HA10: & 19 & 26 & 38 & 49 & \\
\hline & & HA28: & 4 & 6 & 50 & NC & \\
\hline & & CA10: & 29 & 35 & 35 & 50 & \\
\hline $\mathrm{P} 1 \mathrm{~A}$ & 0.75 & & & & $\mathrm{X}$ & & \\
\hline P1B & .66 & & & & $\mathrm{X}$ & & \\
\hline $\mathrm{P} 2 \mathrm{~A}$ & .18 & & & $\mathrm{X}$ & & & \\
\hline $\mathrm{P} 2 \mathrm{~B}$ & .18 & & & $\mathrm{X}$ & & & \\
\hline $\mathrm{P} 2 \mathrm{C}$ & .17 & & & $\mathrm{X}$ & & & \\
\hline $\mathrm{P} 3 \mathrm{~A}$ & .71 & & & & $\mathrm{X}$ & & \\
\hline $\mathrm{P} 3 \mathrm{~B}$ & .16 & & & $\mathrm{X}$ & & & \\
\hline $\mathrm{P} 3 \mathrm{C}$ & .18 & & & $\mathrm{X}$ & & & \\
\hline $\mathrm{P} 4 \mathrm{~A}$ & .27 & & & $\mathrm{X}$ & & & \\
\hline P4B & .28 & & & $\mathrm{X}$ & & & \\
\hline $\mathrm{P} 4 \mathrm{C}$ & .60 & & & & $X$ & & \\
\hline P5A & .27 & & & $X$ & & & \\
\hline P5B & .22 & & & $\mathrm{X}$ & & & \\
\hline $\mathrm{P} 5 \mathrm{C}$ & .18 & & & $\mathrm{X}$ & & & \\
\hline P6A & .46 & & & & $X$ & & \\
\hline P6B & .22 & & & $X$ & & & \\
\hline P6C & .24 & & & $X$ & & & \\
\hline P7A & .28 & & & $X$ & & & \\
\hline P7B & .42 & & & $X$ & & & \\
\hline P7C & .23 & & & $X$ & & & \\
\hline P8A & .78 & & & & $X$ & & \\
\hline P8B & 1.17 & & & & & $X$ & $X$ \\
\hline P9A & .90 & & & & $X$ & & \\
\hline Р9B & .40 & & & $X$ & & & \\
\hline P10 & .38 & & & $X$ & & & \\
\hline $\mathrm{S} 1 \mathrm{~A}$ & .21 & & & $X$ & & & \\
\hline S1B & .23 & & & $X$ & & & \\
\hline $\mathrm{S} 1 \mathrm{C}$ & .23 & & & $X$ & & & \\
\hline $\mathrm{S} 2 \mathrm{~A}$ & .21 & & & $X$ & & & \\
\hline S2B & .22 & & & $X$ & & & \\
\hline $\mathrm{S} 2 \mathrm{C}$ & .22 & & & $X$ & & & \\
\hline $\mathrm{S} 3$ & .22 & & & $X$ & & & \\
\hline S4A & .22 & & & $X$ & & & \\
\hline S4B & .20 & & & $X$ & & & \\
\hline $\mathrm{S} 4 \mathrm{C}$ & .23 & & & $X$ & & & \\
\hline S5 & .20 & & & $X$ & & & \\
\hline B1A & .21 & & & $X$ & & & \\
\hline B1B & .20 & & & $X$ & & & \\
\hline $\mathrm{B} 1 \mathrm{C}$ & .23 & & & $X$ & & & \\
\hline
\end{tabular}




\section{SUMMARY AND CONCLUSIONS}

The U.S. Geological Survey, in cooperation with River Restore, a program within the Massachusetts Executive Office of Environmental Affairs (EOEA), initiated a study to help provide State and Federal agencies with information needed to develop sedimentscreening procedures and protocols to enable rapid and inexpensive surveys of sediment quantity and quality at potential dam-removal sites. The Perryville and Becket impoundments were selected to represent "end members" of the broad range of sediment-chemistry conditions that might be encountered in Massachusetts impoundments. Prior information indicated that the sediments in Perryville Pond would contain high concentrations of contaminants, while the sediments at the Becket sites would show minimal numbers of detections and low concentrations. In a general sense, these expectations were met. Polycyclic aromatic hydrocarbons, total petroleum hydrocarbons, and chlordane in high concentrations were commonly found in samples from Perryville, whereas total petroleum hydrocarbons and polychlorinated biphenyls were not detected at all in Becket samples. The widespread occurrence of polycyclic aromatic hydrocarbons in samples from both locations is a particularly interesting finding; if these compounds are so commonplace in sediments in a setting as rural and undeveloped as Becket, then they are likely to be present in sediments at levels at least as high throughout Massachusetts and elsewhere.

The use of enzyme-linked immunosorbent assays to screen sediment samples for classes of organic compounds proved a highly useful and cost-effective approach; with these screening results in hand, it is relatively easy matter to focus more detailed analysis on areas of known contamination. The U.S. Army Corps of Engineers, the U.S. Navy, and the USEPA apply and recommend similar approaches.

In this study, GPR proved to be of limited usefulness for measuring sediment thickness in impoundments containing boulders, ledges, and heterogeneous bottom materials. Although detailed information was obtained, it was difficult and timeconsuming to interpret the raw data; in the end, a simpler method, manual probing with a rod, proved more effective. Nevertheless, reaching such a conclusion represents another important finding of this study.
Collecting numerous sediment cores led to an improved understanding of the variability of contaminant concentrations, particularly in the Perryville impoundment. The number of sediment cores collected and samples analyzed were adequate for minimal regulatory screening requirements; however, minimal does not imply that, for example, only two samples would be required in a system known to be highly contaminated. Because of the potential for horizontal and vertical variability, analysis of too few surface grab samples alone could lead to misleading interpretations. Determining the mean concentrations of particular analytes within a specified confidence interval requires a more rigorous approach to identifying the number of samples to collect. In an heuristic example, the number of samples analyzed was sufficient to adequately characterize the mean concentrations of most of the analytes in all the impoundments. However, at Perryville, some of the contaminants with highly variable concentrations, such as $\mathrm{Cu}, \mathrm{Zn}, \mathrm{Pb}, \mathrm{As}, \mathrm{TPH}$, and chlordane, would have required additional samples to characterize the mean on the basis of our assumptions and parameters.

Using manual coring techniques to collect samples proved exhausting and frustrating at times. The option of using a lightweight, motorized, piston corer could improve the entire sampling process; however, accessibility and cost may preclude its use in particular locations.

From this experience, it seems that a phased approach is essential for sediment-characterization studies. After completing the due-diligence phase, a thorough reconnaissance of the site, including a preliminary examination of sediment and basin physical parameters prior to sample collection, should be conducted. A preliminary screening round of sampling and analysis can guide more thorough, focused sampling, if deemed necessary. Determining the physical characteristics of the sediment can guide sampling efforts toward areas where are likely contaminants associated with clays and other fine particles.

The application of the consensus-based guidelines by using the Probable Effect Concentration values is a new approach that gives an assessment of potential sediment toxicity to invertebrate test organisms at sites where multiple contaminants are present. In this study, the results suggest the existence of a few pockets of toxic sediments at Perryville Pond; 
data from the Becket sediments do not indicate the existence of similar "hot spots." However, geographic differences may also prove important in interpreting data; the consensus-based guidelines used few data from studies in the northeastern United States. Currently, this approach to assessing sediment toxicity remains under development; there are other permutations of analyzing these data that could be applied. For example, individual contaminants or compounds, instead of compound classes, could be weighted, or additional potentially toxic analytes could be included. Moreover, different compounds or classes of compounds likely contribute unequally to overall sediment toxicity. The methods described for predicting sediment toxicity offer promise and further development of the methods deserves encouragement and thorough testing.

\section{REFERENCES CITED}

Aga, D.S., Thurman, E.M., and Pomes, M.L., 1994, Determination of alachlor and its sulfonic acid metabolite in water by solid-phase extraction and enzyme-linked immunosorbent assay: Analytical Chemistry, v. 66, p. 1495-1499.

Breault, R.F., Reisig, K.R., Barlow, L.K., and Weiskel, P.K., 2000, Distribution and potential for adverse biological effects of inorganic elements and organic compounds in bottom sediment, lower Charles River, Massachusetts, U.S. Geological Survey Water-Resources Investigations Report 00-4180, 70 p.

Ecosystem Conservation Directorate Evaluation and Interpretation Branch, 1995, Interim sediment quality guidelines: Ottawa, Ontario, Canada, Soil and Sediment Quality Section, Guidelines Division, 12 p.

Federal Remediation Technologies Roundtable, 2002, FRTR field sampling and analysis guide: Federal Remediation Technologies Roundtable, accessed November 6, 2002, at URL, http://www.frtr.gov/site/analysismatrix.html

Gruessner, B., Shambaugh, N.C., and Watzin, M.C., 1995, Comparison of an enzyme immunoassay and gas chromatography/mass spectrometry for the detection of atrazine in surface waters: Environmental Science and Technology, v. 29, p. 251-254.
Guy, H.P., 1969, Laboratory theory and methods for sediment analysis: U.S. Geological Survey Techniques of Water-Resources Investigations, book 5, chap. C1, $58 \mathrm{p}$.

Hakanson, L., 1984, Sediment sampling in different aquatic environments-Statistical aspects: Water Resources Research, v. 20, p. 41-46.

Harris, S.L., 1997, Inorganic and organic constituents and grain-size distribution in streambed sediment and ancillary data for the Connecticut, Housatonic, and Thames River Basins study unit, 1992-94: U.S. Geological Survey Open-File Report 96-397, 39 p.

Horowitz, A.J., 1991, A primer on sediment-trace element chemistry ( $2 \mathrm{~d}$ ed.): Boca Raton, FL, Lewis Publishers, $136 \mathrm{p}$.

Kirtay, V.J., and Apitz, S.E., 2000, Rapid sediment characterization (RSC) tools for ecological risk assessments: Argonne National Laboratory, Environmental Assessment Division, Issue Paper, accessed on November 6, 2002, at URL http://web.ead.anl.gov/ecorisk/issue/pdf/rsc.pdf, 22 p.

Kratochvil, B., and Taylor, J.K., 1981, Sampling for chemical analysis: Analytical Chemistry, v. 53, p. 924A-938A.

Schulze, P.A., Capel, P.D., Squillace, P.J., and Helsel, D.R., 1990, A laboratory and field evaluation of a portable immunoassay test for triazine herbicides in environmental water samples: U.S. Geological Survey Office of Water Quality Technical Memorandum 90.08, $22 \mathrm{p}$.

U.S. Army Corps of Engineers, 2000, Site assessment report and risk characterization of PCBs at Birch Hill Reservoir, Royalston, Massachusetts: Task Order 28, Contract DACW33-96-D-0004, variously paged.

U.S. Environmental Protection Agency, 1987, Final environmental impact statement for the French River cleanup program in Massachusetts and Connecticut: Boston, MA, U.S. Environmental Protection Agency, variously paged.

2000a, Analytical method guidance for EPA method 1664A implementation and use (40 CFR part 136): EPA/821-R-00-003, 44 p.

2000b, Prediction of sediment toxicity using consensus-based freshwater sediment guidelines: EPA 905/R-00-007, 33 p. 


\section{Appendix: Complete Listing of Elemental Analyses Performed by XRAL Laboratories, Inc.}



Appendix. Results of elemental analyses performed by XRAL Laboratories, Inc., Ontario, Canada

[Q, indicates quality-control duplicate sample; $\mathrm{mg} / \mathrm{kg}$, milligrams per kilogram; \%, percent; $<$, actual value is less than value shown]

\begin{tabular}{|c|c|c|c|c|c|c|c|c|c|c|}
\hline Sample & $\begin{array}{c}\text { Antimony } \\
(\mathrm{mg} / \mathrm{kg})\end{array}$ & $\begin{array}{l}\text { Arsenic } \\
\text { (mg/kg) }\end{array}$ & $\begin{array}{l}\text { Barium } \\
(\mathrm{mg} / \mathrm{kg})\end{array}$ & $\begin{array}{c}\text { Beryllium } \\
\text { (mg/kg) }\end{array}$ & $\begin{array}{l}\text { Bismuth } \\
\text { (mg/kg) }\end{array}$ & $\begin{array}{l}\text { Cadmium } \\
\text { (mg/kg) }\end{array}$ & $\begin{array}{c}\text { Calcium } \\
(\%)\end{array}$ & $\begin{array}{c}\text { Cobalt } \\
(\mathrm{mg} / \mathrm{kg})\end{array}$ & $\begin{array}{l}\text { Copper } \\
\text { (mg/kg) }\end{array}$ & $\begin{array}{l}\text { Iron } \\
(\%)\end{array}$ \\
\hline P1A & 6 & 12 & 165 & 0.5 & $<5$ & 2 & 0.21 & 5 & 336 & 1.65 \\
\hline P1B & $<5$ & 6 & 83 & $<.5$ & $<5$ & 1 & .15 & 5 & 116 & 1.13 \\
\hline $\mathrm{P} 2 \mathrm{~A}$ & $<5$ & 4 & 23 & .8 & $<5$ & $<1$ & .17 & 8 & 9.6 & 1.46 \\
\hline P2B & $<5$ & 8 & 18 & .8 & $<5$ & $<1$ & .11 & 7 & 6.1 & 1.49 \\
\hline $\mathrm{P} 2 \mathrm{C}$ & $<5$ & 8 & 31 & .8 & $<5$ & $<1$ & .13 & 6 & 4.4 & 1.83 \\
\hline P3A & $<5$ & 14 & 91 & .6 & $<5$ & 2 & .25 & 7 & 258 & 1.59 \\
\hline P3B & $<5$ & 4 & 16 & .7 & $<5$ & $<1$ & .1 & 5 & 5.3 & 1.35 \\
\hline P3C & $<5$ & 10 & 40 & .9 & $<5$ & $<1$ & .16 & 10 & 5.1 & 2.01 \\
\hline $\mathrm{P} 4 \mathrm{~A}$ & $<5$ & 3 & 112 & $<.5$ & $<5$ & $<1$ & .15 & 4 & 25.6 & 1 \\
\hline P4B & $<5$ & 6 & 46 & $<.5$ & $<5$ & $<1$ & .12 & 2 & 29.4 & .83 \\
\hline P4B-Q & $<5$ & 6 & 113 & $<.5$ & $<5$ & 1 & .19 & 4 & 226 & 1.34 \\
\hline $\mathrm{P} 4 \mathrm{C}$ & $<5$ & 8 & 122 & $<.5$ & $<5$ & 2 & .21 & 4 & 239 & 1.46 \\
\hline P5A & $<5$ & 4 & 36 & $<.5$ & $<5$ & $<1$ & .13 & 4 & 27.7 & .9 \\
\hline P5B & $<5$ & $<3$ & 18 & $<.5$ & $<5$ & $<1$ & .09 & 3 & 9 & .71 \\
\hline P5C & $<5$ & 8 & 18 & .6 & $<5$ & $<1$ & .13 & 2 & 3 & 1 \\
\hline P6A & $<5$ & 7 & 122 & .8 & $<5$ & 2 & .21 & 5 & 247 & 1.54 \\
\hline P6B & $<5$ & $<3$ & 30 & $<.5$ & $<5$ & $<1$ & .15 & 2 & 12.2 & .87 \\
\hline P6C & $<5$ & $<3$ & 29 & $<.5$ & $<5$ & $<1$ & .14 & 3 & 16.1 & .87 \\
\hline P7A & $<5$ & 5 & 48 & $<.5$ & $<5$ & $<1$ & .18 & 4 & 40.2 & 1.16 \\
\hline P7B & $<5$ & 9 & 55 & $<.5$ & $<5$ & 2 & .16 & 4 & 161 & .96 \\
\hline P7C & $<5$ & $<3$ & 28 & $<.5$ & $<5$ & $<1$ & .12 & 2 & 10.5 & .72 \\
\hline P8A & 11 & 35 & 219 & 1.5 & $<5$ & 5 & .34 & 9 & 346 & 1.67 \\
\hline P8A-Q & 10 & 32 & 197 & 1.8 & $<5$ & 4 & .33 & 9 & 316 & 1.58 \\
\hline P8B & 15 & 54 & 164 & .9 & $<5$ & 5 & .34 & 7 & 734 & 1.83 \\
\hline P9A & 14 & 28 & 108 & .8 & $<5$ & 10 & .36 & 6 & 533 & 1.93 \\
\hline P9B & $<5$ & 10 & 58 & .6 & $<5$ & 2 & .2 & 6 & 194 & 1.21 \\
\hline P10 & $<5$ & 59 & 51 & .5 & $<5$ & $<1$ & .3 & 4 & 44.9 & 2.84 \\
\hline P10-Q & $<5$ & 59 & 52 & .5 & $<5$ & $<1$ & .3 & 4 & 44.2 & 2.81 \\
\hline S1A & $<5$ & $<3$ & 70 & $<.5$ & $<5$ & $<1$ & .37 & 8 & 9.8 & 1.79 \\
\hline S1B & $<5$ & $<3$ & 58 & $<.5$ & $<5$ & $<1$ & .44 & 7 & 12.4 & 2.03 \\
\hline S1C & $<5$ & $<3$ & 50 & $<.5$ & $<5$ & $<1$ & .29 & 6 & 6.6 & 1.79 \\
\hline $\mathrm{S} 2 \mathrm{~A}$ & $<5$ & $<3$ & 74 & $<.5$ & $<5$ & $<1$ & .41 & 9 & 11.7 & 2.4 \\
\hline S2B & $<5$ & $<3$ & 78 & $<.5$ & $<5$ & $<1$ & .35 & 7 & 12.2 & 2.28 \\
\hline $\mathrm{S} 2 \mathrm{C}$ & $<5$ & $<3$ & 99 & .5 & $<5$ & $<1$ & .46 & 7 & 16.4 & 2.11 \\
\hline S3 & $<5$ & $<3$ & 65 & $<.5$ & $<5$ & $<1$ & .34 & 6 & 10.1 & 1.73 \\
\hline S4A & $<5$ & $<3$ & 57 & $<.5$ & $<5$ & $<1$ & .43 & 6 & 9.3 & 1.8 \\
\hline S4B & $<5$ & $<3$ & 58 & $<.5$ & $<5$ & $<1$ & .33 & 6 & 8.4 & 1.75 \\
\hline $\mathrm{S} 4 \mathrm{C}$ & $<5$ & $<3$ & 49 & $<.5$ & $<5$ & $<1$ & .31 & 7 & 7.7 & 1.79 \\
\hline S5 & $<5$ & $<3$ & 39 & $<.5$ & $<5$ & $<1$ & .25 & 4 & 6.7 & 1.51 \\
\hline B1A & $<5$ & $<3$ & 81 & $<.5$ & $<5$ & $<1$ & .41 & 8 & 11.5 & 2.1 \\
\hline
\end{tabular}


Appendix. Results of elemental analyses performed by XRAL Laboratories, Inc., Ontario, Canada_Continued

\begin{tabular}{lcccccccccc}
\hline Sample & $\begin{array}{c}\text { Antimony } \\
(\mathbf{m g} / \mathbf{k g})\end{array}$ & $\begin{array}{c}\text { Arsenic } \\
(\mathbf{m g} / \mathbf{k g})\end{array}$ & $\begin{array}{c}\text { Barium } \\
(\mathbf{m g} / \mathbf{k g})\end{array}$ & $\begin{array}{c}\text { Beryllium } \\
(\mathbf{m g} / \mathbf{k g})\end{array}$ & $\begin{array}{c}\text { Bismuth } \\
(\mathbf{m g} / \mathbf{k g})\end{array}$ & $\begin{array}{c}\text { Cadmium } \\
(\mathbf{m g} / \mathbf{k g})\end{array}$ & $\begin{array}{c}\text { Calcium } \\
(\mathbf{\%})\end{array}$ & $\begin{array}{c}\text { Cobalt } \\
(\mathbf{m g} / \mathbf{k g})\end{array}$ & $\begin{array}{c}\text { Copper } \\
(\mathbf{m g} / \mathbf{k g})\end{array}$ & $\begin{array}{c}\text { Iron } \\
(\mathbf{\%})\end{array}$ \\
\hline B1A-Q & $<5$ & $<3$ & 83 & $<0.5$ & $<5$ & $<1$ & 0.42 & 9 & 11.5 & 2.12 \\
B1B & $<5$ & $<3$ & 39 & $<.5$ & $<5$ & $<1$ & .24 & 5 & 7.3 & 1.32 \\
B1C & $<5$ & $<3$ & 51 & $<.5$ & $<5$ & $<1$ & .38 & 6 & 10.1 & 1.72 \\
\hline
\end{tabular}

\begin{tabular}{|c|c|c|c|c|c|c|c|c|c|c|}
\hline Sample & $\begin{array}{c}\text { Lanthanum } \\
(\mathrm{mg} / \mathrm{kg})\end{array}$ & $\begin{array}{l}\text { Lead } \\
\text { (mg/kg) }\end{array}$ & $\begin{array}{l}\text { Lithium } \\
\text { (mg/kg) }\end{array}$ & $\begin{array}{l}\text { Magnesium } \\
(\%)\end{array}$ & $\begin{array}{l}\text { Manganese } \\
(\mathrm{mg} / \mathrm{kg})\end{array}$ & $\begin{array}{l}\text { Nickel } \\
\text { (mg/kg) }\end{array}$ & $\begin{array}{l}\text { Molybdenum } \\
\text { (mg/kg) }\end{array}$ & $\begin{array}{l}\text { Phosphorus } \\
(\%)\end{array}$ & $\begin{array}{c}\text { Potassium } \\
(\%)\end{array}$ & $\begin{array}{c}\text { Scandium } \\
\text { (mg/kg) }\end{array}$ \\
\hline P1A & 13.4 & 250 & 15 & 0.26 & 159 & 22 & 3 & 0.13 & 0.14 & 1.1 \\
\hline P1B & 12.1 & 219 & 13 & .22 & 108 & 18 & 3 & .09 & .11 & .9 \\
\hline $\mathrm{P} 2 \mathrm{~A}$ & 24.3 & 13 & 23 & .3 & 347 & 16 & 2 & .05 & .08 & 1.3 \\
\hline $\mathrm{P} 2 \mathrm{~B}$ & 25.4 & 11 & 25 & .38 & 238 & 19 & 2 & .05 & .06 & 1.7 \\
\hline $\mathrm{P} 2 \mathrm{C}$ & 31.8 & 5 & 26 & .45 & 203 & 19 & 1 & .03 & .09 & 2.6 \\
\hline P3A & 17.1 & 213 & 18 & .35 & 256 & 22 & 2 & .14 & .18 & 1.3 \\
\hline P3B & 25.7 & 5 & 25 & .33 & 173 & 16 & 1 & .04 & .07 & 1.6 \\
\hline $\mathrm{P} 3 \mathrm{C}$ & 33.3 & 5 & 32 & .53 & 228 & 21 & 2 & .04 & .11 & 3 \\
\hline P4A & 12.2 & 64 & 13 & .23 & 110 & 13 & 2 & .05 & .16 & 1.2 \\
\hline P4B & 10.2 & 68 & 12 & .2 & 82 & 14 & 2 & .05 & .11 & 1 \\
\hline P4B-Q & 26.2 & 163 & 13 & .22 & 118 & 21 & 2 & .1 & .14 & 1 \\
\hline $\mathrm{P} 4 \mathrm{C}$ & 27.7 & 179 & 14 & .24 & 128 & 21 & 2 & .11 & .15 & 1 \\
\hline P5A & 12.2 & 67 & 13 & .2 & 122 & 16 & 2 & .06 & .12 & 1 \\
\hline P5B & 11.2 & 9 & 12 & .17 & 94 & 11 & 2 & .07 & .05 & .6 \\
\hline P5C & 21.6 & 5 & 17 & .25 & 149 & 11 & 1 & .03 & .07 & 1.3 \\
\hline P6A & 32.3 & 211 & 19 & .35 & 249 & 24 & 3 & .18 & .13 & 1.1 \\
\hline P6B & 14.5 & 9 & 14 & .21 & 105 & 11 & 1 & .08 & .07 & .7 \\
\hline P6C & 16 & 15 & 18 & .28 & 111 & 14 & 1 & .06 & .06 & .9 \\
\hline P7A & 14 & 58 & 11 & .2 & 201 & 17 & 3 & .08 & .12 & .8 \\
\hline P7B & 15.9 & 187 & 13 & .22 & 139 & 14 & 2 & .1 & .11 & .9 \\
\hline P7C & 12.3 & 20 & 12 & .2 & 96 & 10 & $<1$ & .07 & .08 & .7 \\
\hline P8A & 29.1 & 459 & 21 & .35 & 196 & 26 & 3 & .24 & .17 & 1.8 \\
\hline P8A-Q & 26.2 & 420 & 20 & .33 & 184 & 25 & 3 & .22 & .16 & 1.9 \\
\hline P8B & 24.9 & 528 & 26 & .46 & 157 & 22 & 2 & .28 & .25 & 1.4 \\
\hline P9A & 22.1 & 515 & 24 & .46 & 207 & 20 & 2 & .16 & .31 & 2.1 \\
\hline P9B & 16 & 136 & 19 & .31 & 126 & 16 & 2 & .11 & .14 & 1.1 \\
\hline P10 & 14.7 & 72 & 16 & .29 & 240 & 15 & 2 & .13 & .16 & 1.1 \\
\hline P10-Q & 15.8 & 67 & 16 & .29 & 238 & 16 & 2 & .13 & .16 & 1.2 \\
\hline S1A & 9.7 & 17 & 10 & .31 & 206 & 18 & 3 & .08 & .18 & 1.7 \\
\hline S1B & 10 & 15 & 10 & .32 & 227 & 14 & 2 & .08 & .21 & 2.3 \\
\hline S1C & 9 & 12 & 9 & .27 & 198 & 11 & 2 & .08 & .2 & 1.8 \\
\hline S2A & 12.7 & 26 & 13 & .37 & 430 & 15 & 3 & .1 & .24 & 2.4 \\
\hline S2B & 12.8 & 37 & 15 & .39 & 338 & 17 & 3 & .1 & .23 & 1.8 \\
\hline S2C & 14.3 & 43 & 16 & .44 & 196 & 15 & 3 & .09 & .27 & 2.2 \\
\hline S3 & 10.6 & 29 & 12 & 0.34 & 228 & 13 & 2 & 0.08 & 0.2 & 1.7 \\
\hline
\end{tabular}


Appendix. Results of elemental analyses performed by XRAL Laboratories, Inc., Ontario, Canada_Continued

\begin{tabular}{|c|c|c|c|c|c|c|c|c|c|c|}
\hline Sample & $\begin{array}{c}\text { Lanthanum } \\
(\mathbf{m g} / \mathbf{k g})\end{array}$ & $\begin{array}{c}\text { Lead } \\
(\mathrm{mg} / \mathrm{kg})\end{array}$ & $\begin{array}{l}\text { Lithium } \\
\text { (mg/kg) }\end{array}$ & $\begin{array}{l}\text { Magnesium } \\
(\%)\end{array}$ & $\begin{array}{l}\text { Manganese } \\
(\mathrm{mg} / \mathrm{kg})\end{array}$ & $\begin{array}{l}\text { Nickel } \\
\text { (mg/kg) }\end{array}$ & $\begin{array}{l}\text { Molybdenum } \\
(\mathbf{m g} / \mathbf{k g})\end{array}$ & $\begin{array}{l}\text { Phosphorus } \\
(\%)\end{array}$ & $\begin{array}{l}\text { Potassium } \\
(\%)\end{array}$ & $\begin{array}{c}\underset{\text { Scandium }}{(\mathrm{mg} / \mathrm{kg})} \\
\text {. }\end{array}$ \\
\hline S4A & 9.5 & 11 & 9 & .32 & 355 & 13 & 2 & .08 & .2 & 2 \\
\hline S4B & 1.6 & 15 & 11 & .3 & 211 & 13 & 2 & .09 & .19 & 1.6 \\
\hline $\mathrm{S} 4 \mathrm{C}$ & 1.5 & 15 & 10 & .29 & 227 & 10 & 2 & .07 & .19 & 2.1 \\
\hline S5 & 8.6 & 14 & 9 & .25 & 190 & 12 & 2 & .06 & .17 & 1.6 \\
\hline B1A & 12.6 & 20 & 13 & .4 & 328 & 14 & 3 & .09 & .24 & 2 \\
\hline B1A-Q & 12.3 & 20 & 13 & .41 & 332 & 14 & 3 & .1 & .25 & 2.1 \\
\hline B1B & 8.4 & 11 & 8 & .26 & 145 & 11 & 1 & .06 & .18 & 1.6 \\
\hline $\mathrm{B} 1 \mathrm{C}$ & 10.5 & 12 & 9 & .33 & 224 & 12 & 2 & .07 & .23 & 2.4 \\
\hline
\end{tabular}

\begin{tabular}{|c|c|c|c|c|c|c|c|c|c|c|}
\hline Sample ID & $\begin{array}{c}\text { Silver } \\
\text { (mg/kg) }\end{array}$ & $\begin{array}{c}\text { Sodium } \\
(\%)\end{array}$ & $\begin{array}{c}\text { Strontium } \\
(\mathrm{mg} / \mathrm{kg})\end{array}$ & $\underset{\text { Tin }}{\text { Ting/kg) }}$ & $\begin{array}{l}\text { Titanium } \\
(\%)\end{array}$ & $\begin{array}{c}\text { Tungsten } \\
\text { (mg/kg) }\end{array}$ & $\begin{array}{c}\text { Vanadium } \\
\text { (mg/kg) }\end{array}$ & $\begin{array}{l}\text { Yttrium } \\
\text { (mg/kg) }\end{array}$ & $\begin{array}{c}\text { Zinc } \\
(\mathbf{m g} / \mathbf{k g})\end{array}$ & $\underset{(\mathrm{mg} / \mathrm{kg})}{\text { Zirconium }}$ \\
\hline P1A & 5.2 & 0.04 & 17.5 & $<10$ & 0.04 & $<10$ & 24 & 6.8 & 385 & 6.4 \\
\hline P1B & .4 & .03 & 16.7 & 16 & .03 & $<10$ & 15 & 5.6 & 288 & 2.6 \\
\hline $\mathrm{P} 2 \mathrm{~A}$ & $<.2$ & .04 & 11.6 & $<10$ & .08 & $<10$ & 18 & 12.7 & 27.6 & 2.5 \\
\hline $\mathrm{P} 2 \mathrm{~B}$ & .3 & .03 & 7.3 & $<10$ & .09 & $<10$ & 21 & 15.1 & 25.8 & 2.2 \\
\hline $\mathrm{P} 2 \mathrm{C}$ & $<.2$ & .04 & 9.7 & $<10$ & .1 & $<10$ & 26 & 16.9 & 27.1 & 3.5 \\
\hline P3A & 1 & .04 & 19.4 & $<10$ & .05 & $<10$ & 23 & 7.8 & 499 & 3 \\
\hline P3B & .3 & .03 & 7.2 & $<10$ & .08 & $<10$ & 18 & 12.3 & 21.5 & 2.3 \\
\hline $\mathrm{P} 3 \mathrm{C}$ & $<.2$ & .04 & 10.9 & $<10$ & .11 & $<10$ & 30 & 17.6 & 31.6 & 3.2 \\
\hline $\mathrm{P} 4 \mathrm{~A}$ & $<.2$ & .04 & 16.7 & $<10$ & .03 & $<10$ & 12 & 4.7 & 74.3 & 4.5 \\
\hline P4B & .3 & .03 & 12.6 & $<10$ & .02 & $<10$ & 11 & 3.8 & 59.3 & 3.9 \\
\hline P4B-Q & 2.9 & .04 & 15.8 & $<10$ & .03 & $<10$ & 20 & 5 & 247 & 5.8 \\
\hline $\mathrm{P} 4 \mathrm{C}$ & 2.9 & .04 & 16.9 & $<10$ & .03 & $<10$ & 21 & 5.3 & 263 & 5.4 \\
\hline P5A & .3 & .03 & 10.7 & $<10$ & .03 & $<10$ & 11 & 4.3 & 51.5 & 3 \\
\hline P5B & $<.2$ & .03 & 7.5 & $<10$ & .03 & $<10$ & 8 & 4.2 & 12.2 & .9 \\
\hline $\mathrm{P} 5 \mathrm{C}$ & .3 & .03 & 8.5 & $<10$ & .06 & $<10$ & 14 & 8.8 & 13.7 & 2.6 \\
\hline P6A & 1.6 & .04 & 17.8 & $<10$ & .05 & $<10$ & 33 & 8.2 & 177 & 4.3 \\
\hline P6B & $<.2$ & .04 & 10.3 & $<10$ & .04 & $<10$ & 11 & 5.5 & 28.1 & 1.4 \\
\hline $\mathrm{P} 6 \mathrm{C}$ & $<.2$ & .03 & 8 & $<10$ & .05 & $<10$ & 13 & 6.2 & 29.8 & 1 \\
\hline P7A & .4 & .05 & 13.9 & $<10$ & .03 & $<10$ & 13 & 5.6 & 69 & 2.3 \\
\hline P7B & 1 & .03 & 12.8 & $<10$ & .03 & $<10$ & 13 & 5.2 & 218 & 2.6 \\
\hline $\mathrm{P} 7 \mathrm{C}$ & $<.2$ & .03 & 8.1 & $<10$ & .03 & $<10$ & 9 & 4.5 & 20.7 & 1 \\
\hline P8A & 3.4 & .05 & 36.8 & 15 & .04 & $<10$ & 26 & 10 & 897 & 4.6 \\
\hline P8A-Q & 3.6 & .04 & 34.5 & 12 & .04 & $<10$ & 26 & 9.4 & 823 & 4.8 \\
\hline P8B & 2.7 & .05 & 29.9 & 30 & .05 & $<10$ & 27 & 11.6 & 842 & 3.6 \\
\hline P9A & 1.1 & .06 & 27.3 & 63 & .05 & $<10$ & 26 & 11.2 & 824 & 5.7 \\
\hline P9B & .2 & .04 & 13 & 68 & .05 & $<10$ & 16 & 7.5 & 134 & 1.8 \\
\hline P10 & .5 & .06 & 20 & $<10$ & .04 & $<10$ & 19 & 7.8 & 75 & 3.2 \\
\hline P10-Q & .5 & .07 & 20.2 & $<10$ & .04 & $<10$ & 19 & 7.7 & 74.6 & 3.6 \\
\hline S1A & $<.2$ & .03 & 10.8 & $<10$ & .07 & $<10$ & 17 & 8.4 & 65.9 & 1.6 \\
\hline S1B & $<0.2$ & 0.07 & 12.2 & $<10$ & 0.08 & $<10$ & 20 & 9.1 & 61.6 & 2.4 \\
\hline
\end{tabular}


Appendix. Complete listing of elemental analyses performed by XRAL Laboratories, Inc., Ontario, Canada—Continued

\begin{tabular}{lcccccccccc}
\hline \multicolumn{1}{c}{ Sample ID } & $\begin{array}{c}\text { Silver } \\
(\mathbf{m g} / \mathbf{k g})\end{array}$ & $\begin{array}{c}\text { Sodium } \\
(\mathbf{\%})\end{array}$ & $\begin{array}{c}\text { Strontium } \\
(\mathbf{m g} / \mathbf{k g})\end{array}$ & $\begin{array}{c}\text { Tin } \\
(\mathbf{m g} / \mathbf{k g})\end{array}$ & $\begin{array}{c}\text { Titanium } \\
(\mathbf{\%})\end{array}$ & $\begin{array}{c}\text { Tungsten } \\
(\mathbf{m g} / \mathbf{k g})\end{array}$ & $\begin{array}{c}\text { Vanadium } \\
(\mathbf{m g} / \mathbf{k g})\end{array}$ & $\begin{array}{c}\text { Yttrium } \\
(\mathbf{m g} / \mathbf{k g})\end{array}$ & $\begin{array}{c}\text { Zinc } \\
(\mathbf{m g} / \mathbf{k g})\end{array}$ & $\begin{array}{c}\text { Zirconium } \\
(\mathbf{m g} / \mathbf{k g})\end{array}$ \\
\hline S1C & .3 & .03 & 7.7 & $<10$ & .07 & $<10$ & 15 & 7.6 & 48.4 \\
S2A & $<.2$ & .05 & 10.8 & $<10$ & .1 & $<10$ & 23 & 11.6 & 78.3 & 2.4 \\
S2B & $<.2$ & .03 & 10.8 & $<10$ & .1 & $<10$ & 23 & 10.5 & 89.6 & 1.5 \\
S2C & .2 & .04 & 15.4 & $<10$ & .1 & $<10$ & 24 & 11.5 & 106 & 2.3 \\
S3 & $<.2$ & .03 & 9.9 & $<10$ & .08 & $<10$ & 18 & 8.6 & 72 & 1.4 \\
S4A & $<.2$ & .05 & 10.5 & $<10$ & .08 & $<10$ & 17 & 8.8 & 56.7 \\
S4B & $<.2$ & .03 & 9 & $<10$ & .07 & $<10$ & 16 & 8.5 & 66 \\
S4C & $<.2$ & .04 & 8.8 & $<10$ & .07 & $<10$ & 16 & 8.2 & 51.8 \\
S5 & $<.2$ & .03 & 7.3 & $<10$ & .06 & $<10$ & 13 & 6.3 & 43 \\
B1A & $<.2$ & .04 & 10.6 & $<10$ & .1 & $<10$ & 21 & 10.2 & 87 \\
B1A-Q & $<.2$ & .04 & 11 & $<10$ & .1 & $<10$ & 21 & 10.4 & 2.4 \\
B1B & $<.2$ & .03 & 6.3 & $<10$ & .06 & $<10$ & 12 & 5.9 & 8.7 \\
B1C & .3 & .06 & 9.9 & $<10$ & .08 & $<10$ & 17 & 8.6 & 40.1 \\
\hline
\end{tabular}

